\title{
ON THE HEAT WAVES IN BANGLADESH, THEIR TRENDS AND ASSOCIATED LARGE SCALE TROPOSPHERIC CONDITIONS
}

\author{
Samarendra Karmakar*1 and Mohan Kumar Das ${ }^{1,2}$ \\ ${ }^{1}$ National Oceanographic and Maritime Institute (NOAMI) \\ *Former Director, Bangladesh Meteorological Department and SAARC Meteorological Research Centre \\ ${ }^{2}$ Institute of Water and Flood Management (IWFM), BUET
}

Received: 07 April 2020

Accepted: 03 May 2020

\begin{abstract}
Attempts have been made to study the heat waves along with the trends in Bangladesh and the large-scale tropospheric conditions over Bangladesh and neighbourhood responsible for generating heat waves in the country. Maximum temperature $\left(T_{\max }\right)$ for the period 1981-2016 has been used in the study. Based on the definition of heat waves of Bangladesh Meteorological Department (BMD), the frequencies of days with $T_{\max } \geq$ $36^{\circ} \mathrm{C}$ and $\geq 38^{\circ} \mathrm{C}$ have been computed and their trends are investigated to delineate the areas of heat waves in Bangladesh. During the period 1981-2016, $T_{\max } \geq 36^{\circ} \mathrm{C}$ is found to prevail annually for 79 days at Rajshahi, 51 days at Mongla, 50 days at Khulna in 2014 whereas it is found to prevail annually for 85 days at Chuadanga in 1992, 78 days at Jessore in 2010, 72 days at Satkhira in 1986 and 68 days at Ishurdi in 1995. In 2014, $T_{\max } \geq 36^{\circ} \mathrm{C}$ is found to exist annually for many days in western part of Bangladesh in comparison to the eastern and coastal region of the country. That is why year 2014 has been selected to study heat waves extensively. The study reveals that the monthly, seasonal and annual frequency of $T_{\max } \geq 36^{\circ} \mathrm{C}$ have increasing trends in Bangladesh except a very few places, having the highest increasing trends over southwestern part of the country with increasing rates of 0.816 day/year and 1.02 day/year, respectively at Mongla. The highest increasing trends over southwestern part may be due to the advection and penetration of higher $T_{\max }$ due to northwesterly winds and less rainfall over the area. The seasonal and annual frequencies of $T_{\max } \geq 38^{\circ} \mathrm{C}$ have increasing trends at less than 50\% stations in Bangladesh; some of the increasing trends of the seasonal and annual frequency of maximum temperature $\geq 38^{\circ} \mathrm{C}$ are statistically significant up to $95-99 \%$ level of significance. The large-scale synoptic conditions show that heat waves are found to enter Bangladesh from the west/northwest due to the advection of higher $T_{\max }$ from the west. Heat waves extend from west to east up to about central Bangladesh and a separate area of heat waves develop over the Chittagong Hill Tracts, the reason of which may be due to the diverging pattern of wind flows near the Chittagong Hill Tracts in the year of heat waves. Heat waves are absent along Sandwip-M.Court-Feni-Comilla region. In 2014, heat waves are found to be due to the influence of sub-tropical high over India and its extension over Bangladesh at the surface and at $850 \mathrm{hPa}$ level with strong westerly/northwesterly winds at $850 \mathrm{hPa}$, influence of anticyclones persisting for many days over the Bay of Bengal at $300 \mathrm{hPa}$ level, absence of upper level westerly troughs over India and Bangladesh.
\end{abstract}

Key words: Heat waves; maximum temperature; anticyclones; westerly troughs; sub-tropical high.

\section{INTRODUCTION}

Bangladesh is affected by a number of meteorological phenomena because of its unique geographical location, having the Himalayas in the north and the Bay of Bengal in the south. Of these phenomena, heat waves are common in Bangladesh especially during the pre-monsoon season (March-May). These heat waves with persistent extreme high temperatures have been occurring over the country with disastrous consequences for human and animals' health, economies, and ecosystems. As such the study of heat waves, their trends, and the meteorological causes responsible for heat waves are important for the safety of animal and animal health, agriculture, economic planning, etc. In Bangladesh, a few studies have been made by some authors (Karmakar, 2019; Nissan et al., 2017; Hashizume et al., 2008) but a number of studies have been made in India (Ratnam et al., 2016; Pai et al., 2013; Mishra et al., 2015; Panda et al., 2017; Mitra et al., 2017; De and Mukhopadhyay, 1998; De et al., 2004; Murari et al., 2015; Ghatak et al., 2017).

Karmakar (2019) has found that Rajshahi has the highest mean frequency of maximum temperature $>36^{\circ} \mathrm{C}$ in the month of May, whereas Dinajpur and Rangpur have the maximum mean frequency of maximum temperature $>36^{\circ} \mathrm{C}$ in the month of April. Heat waves will be long lasting in Rajshahi during April-July. The annual frequency of heat wave days with $T_{\max }>36^{\circ} \mathrm{C}$ has increasing tendency in northwest Bangladesh. According to Ratnam et al. (2016), India suffers from major heat waves during March-June. The rising trend of 
number of intense heat waves in recent decades has been vaguely attributed to global warming. Based on the observed patterns and statistical analyses of the maximum temperature variability, they detected two types of heat waves. The first type of heat wave over the north-central India is found to be associated with blocking over the North Atlantic. The blocking over North Atlantic results in a cyclonic anomaly west of North Africa at upper levels. The stretching of vorticity generates a Rossby wave source of anomalous Rossby waves near the entrance of the African Jet. The resulting quasi-stationary Rossby wave-train along the Jet has a positive phase over Indian subcontinent causing anomalous sinking motion and thereby heat wave conditions over India. On the other hand, the second type of heat wave over the coastal eastern India is found to be due to the anomalous Matsuno-Gill response to the anomalous cooling in the Pacific. The Matsuno-Gill response is such that it generates northwesterly anomalies over the landmass reducing the land-sea breeze, resulting in heat waves. Heat waves affect the human comfort and are associated with marked short-term increases in mortality.

Pai et al. (2013) studied the long-term climatology and trends of heat waves during the recent 50 years (19612010) over India. They observed that many areas of India (north, northwest, central and northeast peninsula experienced heat wave days of $\geq 8$ days on an average per season. The north, northwest and central parts of the country were found to experience severe heat waves. Compared with the previous four decades, there was noticeable increase in heat waves/severe heat waves (HW/SHW) days over the country during the recent decade 2001-2010, which is also the warmest decade for the country as well as for the globe. They also concluded that the frequency, persistency and area coverage of the HW/SHW were found to be more than average during succeeding El Nino (El Nino+1) years.

Mishra et al. (2017) in a study mentioned that heat waves with large impacts have increased in the recent past and will continue to increase under future warming. According to them, if the global mean temperature is limited to $2{ }^{\circ} \mathrm{C}$ above pre-industrial conditions, the frequency of severe heat waves will rise by 30 times the current climate by the end- $21^{\text {st }}$ century. In contrast, the frequency is projected to be 2.5 times more (than the low warming scenario of $2^{\circ} \mathrm{C}$ ) under conditions expected if the RCP8.5 'business-as-usual' emissions scenario is followed. Under the $2{ }^{\circ} \mathrm{C}$ low-warming target, population exposure to severe heat waves is projected to increase by about 15 and 92 times the current level by the mid and end- $21^{\text {st }}$ century respectively. Limiting global temperatures to $1.5^{\circ} \mathrm{C}$ above pre-industrial would reduce the exposure by half relative to $8.5 \mathrm{RCP}$ by mid and end- $21^{\text {st }}$ century respectively. If the global temperatures are to exceed $1.5^{\circ} \mathrm{C}$ then substantial measures will be required to offset the large increase in exposure to severe heat waves in India.

Panda et al. (2017) studied the increasing heat waves and warm spells in India, observed from multi aspect framework. This study examines the trends and variability in frequency, duration, and intensity of hot episodes during three time periods (1951-2013, 1981-2013 and 1998-2013) by defining heat waves based on the percentile of maximum, minimum, and mean temperatures. The study also explores heat waves and their relationships with hydroclimatic variables, such as rainfall, terrestrial water storage, Palmer drought severity index, and sea surface temperature. Results reveal that the number, frequency, and duration of daytime heat waves increased considerably during the post-1980 dry and hot phase over a large area. The densely populated and agriculturally dominated northern half of India stands out as a key region where the nighttime heat wave metrics reflected the most pronounced amplifications. Despite the recent warming hiatus in India and other parts of the world, it is found that both daytime and nighttime extreme measures have undergone substantial changes during or in the year following a dry year since 2002, with the probability distribution functions manifesting a hotter-than-normal climate during 1998-2013. This study shows that a few months preceding the 2010 record-breaking heat wave in Russia, India experienced the largest hot episode in the country's history. Interestingly, both these mega events are comparable in terms of their evolution and amplification. These findings emphasize the importance of planning for strategies in the context of the rising co-occurrence of dry and hot events.

The objectives of the present study are to investigate the trends in the frequency of maximum temperature producing heat waves and their distribution in Bangladesh, advection of heat waves in Bangladesh and to find out the areas vulnerable to heat waves. For in-depth study of heat waves, more focus is given to the recent year of maximum heat waves days along with the large-scale circulation patterns and other conditions associated with heat waves for finding out the possible causes for heat waves.

\section{DATA AND METHODOLOGY}

Daily maximum temperature $\left(T_{\max }\right)$ and rainfall over 34 stations for months of January through December during the period 1981-2018 are collected from Bangladesh Meteorological Department (BMD). The stations are shown in Figure 1. The NCEP/NCAR Reanalysis 1 project is using a state-of-the-art analysis/forecast system to perform data assimilation using past data from 1948 to the present. A large subset of this data is available from Physical Sciences laboratory (PSL) in its original 4 times daily format and as daily averages. 
However, the data from 1948-1957 is a little different, in the regular (non-Gaussian) gridded data. The data was done at 8 times daily in the model, because the inputs available in that era were available at 0300, 0900, 1500, and 2100 UTC, whereas the $4 \times$ daily data has been available at $00000,0600,1200$, and 1800UTC. These latter times were forecasted and the combined result for this early era is 8 times daily. The local ingestion process took only the $0000,0600,1200$, and 1800 UTC forecasted values, and thus only those were used to make the daily time series and monthly means here.

In Bangladesh, the classification of heat waves is (Karmakar, 2019):

\begin{tabular}{lc}
\hline \multicolumn{1}{c}{ Types } & Heat waves \\
\hline & Maximum temperature $\left({ }^{\circ} \mathrm{C}\right)$ \\
Mild & $36-38$ \\
Moderate & $38-40$ \\
Severe & $40-42$ \\
Extreme & $>42$ \\
\hline
\end{tabular}

In the present study, days with $T_{\max } \geq 36^{\circ} \mathrm{C}$ and $\geq 38^{\circ} \mathrm{C}$ are computed from the daily data set for the months of January through December during 1981-2016. Monthly, seasonal (Pre-monsoon) and annual frequencies of $T_{\max } \geq 36^{\circ} \mathrm{C}$ and $\geq 38^{\circ} \mathrm{C}$ are determined. Their seasonal (Pre-monsoon) and annual trends and spatial distributions over Bangladesh are studied. It may be mentioned that heat waves were very prominent in 2014 and that is why the large-scale conditions of the troposphere have been studied extensively for this year. NCEP/NCAR Reanalysis 1 project data is used for the preparation of large-scale distribution of different parameters and wind circulations at different levels from surface to $200 \mathrm{hPa}$ for March-May 2014. The results are discussed critically to find out the conditions responsible for the occurrence of heat waves in Bangladesh. The significance of the trends has been tested with the help of F-distribution Test according to the formula (Joost R. van Ginkel, 2019):

$$
F=\frac{R^{2}(n-k)}{(k-1)\left(1-R^{2}\right)}
$$

Where $\mathrm{R}^{2}$ is the coefficient of determination and (n-k) is the degree of freedom.

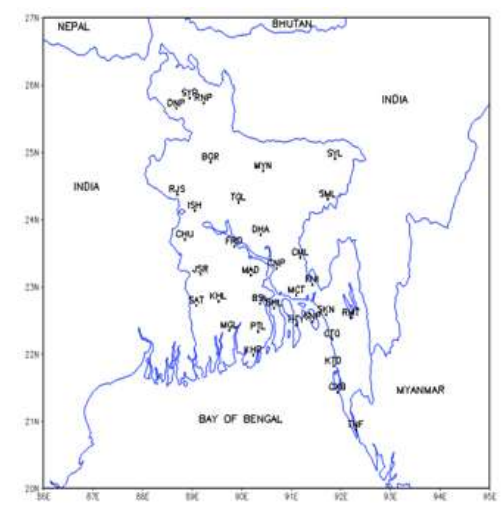

Figure 1: Stations of BMD under study

\section{RESULTS AND DISCUSSION}

The monthly and annual frequencies of days with maximum temperature $\geq 36^{\circ} \mathrm{C}$ and $\geq 38^{\circ} \mathrm{C}$ have been computed for the period 1981-2016 using the daily data on maximum temperature. But the main focus has been made on the pre-monsoon season when extreme heat waves occur over the Bangladesh and surrounding countries. The trends of the frequency of $T_{\max } \geq 36^{\circ} \mathrm{C}$ and $\geq 38^{\circ} \mathrm{C}$ have been computed and studied for 34 stations of BMD. The large scale distributions of maximum temperature as well as the large scale circulation patterns at different levels have also been examined critically to see the causes for the heat waves to occur for the particular year 2014 when the heat waves were persistent and severe over many areas of Bangladesh.

\subsection{Seasonal and annual frequency of maximum temperature $\left(T_{\max }\right) \geq 36^{\circ} \mathrm{C}$ and their trends in Bangladesh}

The seasonal (March-May) and annual frequencies of days with maximum temperature $\geq 36^{\circ} \mathrm{C}$ have been computed using the $T_{\max }$ data for the period 1981-2016. In the annual frequencies of days with $T_{\max } \geq 36^{\circ} \mathrm{C}$, 
$T_{\max }$ of pre-monsoon and monsoon seasons contributes mainly; the post-monsoon and winter seasons do not have any contribution in the heat waves of Bangladesh. In this study, only the pre-monsoon season has been considered as the season because the $T_{\max }$ has great bearings on the people and agriculture of the country. The highest frequency of $T_{\max } \geq 36^{\circ} \mathrm{C}$ during the period 1981-2016 is shown in Figure 2, which shows the highest frequencies of days with $T_{\max } \geq 36^{\circ} \mathrm{C}$ in 2014 are found in 22 stations out of 34 stations i.e. $64.71 \%$ stations but the maximum highest frequencies of days with $T_{\max } \geq 36^{\circ} \mathrm{C}$ are $62,62,60$ and 55 days at Chuadanga in 1995, Ishurdi in 1995, Jessore in 2010 and Rajshahi in 1994, respectively in the pre-monsoon season. In 2014, the heat waves $\left(T_{\max } \geq 36^{\circ} \mathrm{C}\right)$ persisted for many days at many places as is evident from Figure 2 .

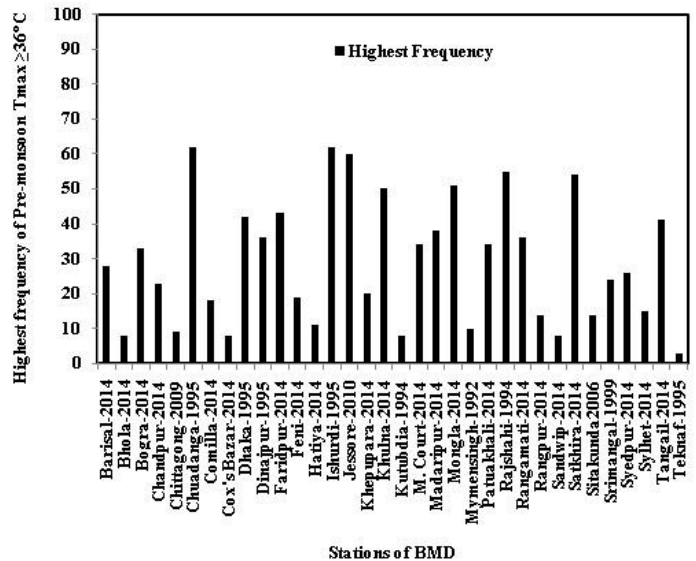

Figure 2: Highest pre-monsoon frequency of days with $T_{\max } \geq 36^{\circ} \mathrm{C}$ in Bangladesh during 1981-2016

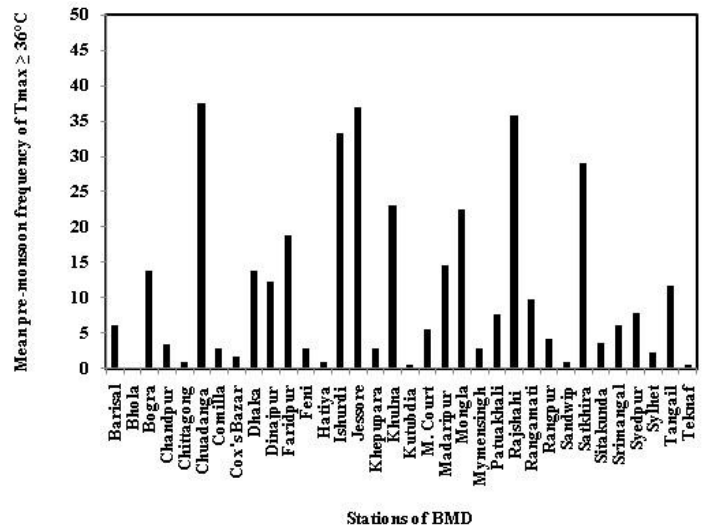

Figure 4: Mean pre-monsoon frequency of days with $T_{\max } \geq 36^{\circ} \mathrm{C}$ in Bangladesh during 1981-2016

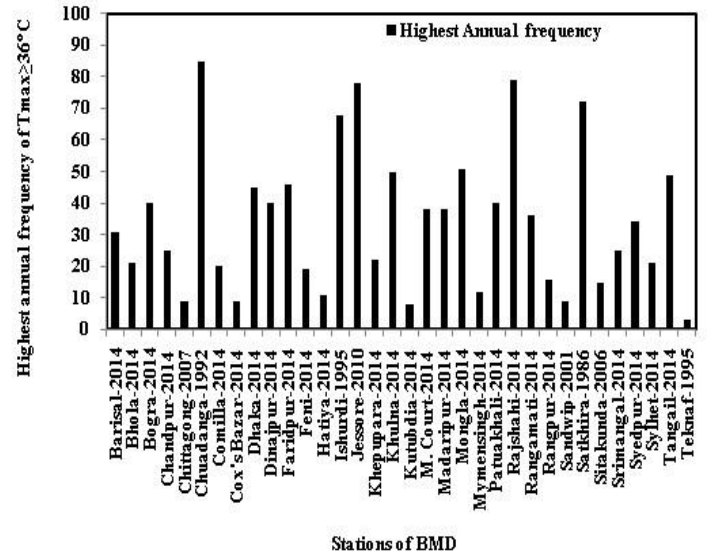

Figure 3: Highest annual frequency of days with $T_{\max } \geq 36^{\circ} \mathrm{C}$ in Bangladesh during 1981-2016

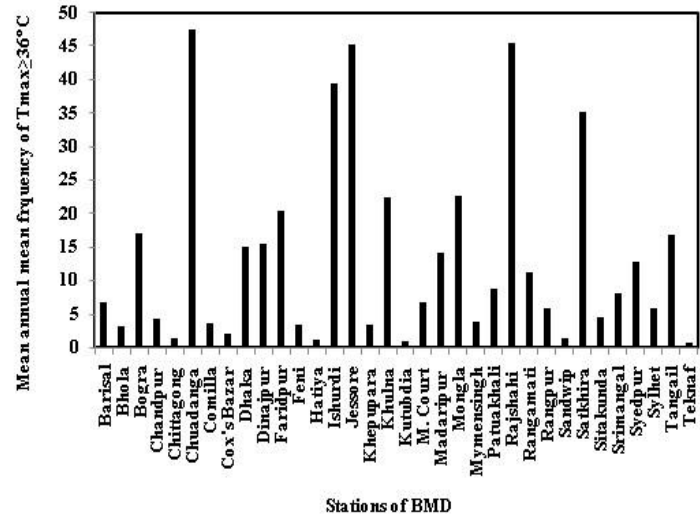

Figure 5: Mean annual frequency of days with $T_{\max } \geq$ $36^{\circ} \mathrm{C}$ in Bangladesh during 1981-2016

Figure 3 shows the highest annual frequency of days with $T_{\max } \geq 36^{\circ} \mathrm{C}$ during 1981-2016 in Bangladesh. It is seen that highest annual frequencies of days with $T_{\max } \geq 36^{\circ} \mathrm{C}$ are in 2014 at $26(76.47 \%)$ out of 34 stations during the period 1981-2016, indicating that the heat waves are found to spread in most places in Bangladesh. In $2014, T_{\max } \geq 36^{\circ} \mathrm{C}$ is found to exist annually for many days in western part of Bangladesh in comparison to the eastern and coastal region of the country. $T_{\max } \geq 36^{\circ} \mathrm{C}$ is found to prevail annually for 79 days at Rajshahi, 51 days at Mongla, 50 days at Khulna in 2014 whereas $T_{\max } \geq 36^{\circ} \mathrm{C}$ is found to prevail annually for 85 days at Chuadanga in 1992, 78 days at Jessore in 2010, 72 days at Satkhira in 1986 and 68 days at Ishurdi in 1995 (Figure 3). This prevailing of $T_{\max } \geq 36^{\circ} \mathrm{C}$ annually is detrimental for the production of crops, vegetables and fruits as well as for the health of human being, cattle and other domestic and wild animals.

Figure 4 shows the mean pre-monsoon frequency of days with $T_{\max } \geq 36^{\circ} \mathrm{C}$ during 1981-2016 in Bangladesh and reveals that higher seasonal mean days of $T_{\max } \geq 36^{\circ} \mathrm{C}$ are $37.57,36.89,35.80,33.21$ and 28.97 at Chuadanga, Jessore, Rajshahi, Ishurdi and Satkhira respectively. The mean annual frequency of days with $T_{\max } \geq 36^{\circ} \mathrm{C}$ during 1981-2016 in Bangladesh is given in Figure 5, which shows that the higher annual mean days of $T_{\max } \geq 36^{\circ} \mathrm{C}$ are 57.57, 45.47, 45.25, 39.50 and 35.28 at Chuadanga, Rajshahi, Jessore, Ishurdi and Satkhira respectively. It is also evident from the figures that the western part of the country has the higher seasonal and annual days with $T_{\max } \geq 36^{\circ} \mathrm{C}$ extending to Tangail-Dhaka-Madaripur-Faridpur region, the highest frequency is at Chuadanga. 
The temporal variations of the seasonal and annual of the frequency of days with $T_{\max } \geq 36^{\circ} \mathrm{C}$ have been considered to find out the trends in the frequency of days with $T_{\max } \geq 36^{\circ} \mathrm{C}$; the results are given in Table 1 . The table shows that the seasonal frequency of days with $T_{\max } \geq 36^{0} \mathrm{C}$ has increasing trends at 28 out of 34 stations $(82.35 \%)$ with the highest rate of +0.816 day/year at Mongla and the second highest rate of +0.509 day/year at Patuakhali. The increasing rates of seasonal frequency of days with $T_{\max } \geq 36^{0} \mathrm{C}$ are statistically significant at about $50 \%$ stations up to $95-99 \%$ level of significance. While the annual frequency of days with $T_{\max } \geq 36^{\circ} \mathrm{C}$ has increasing trends at 29 out of 34 stations $(85.29 \%)$ with the highest rate of +1.018 day/year at Mongla and the second highest rate of +0.750 day/year at Jessore. These two rates are highly significant at $99 \%$ level of significance. In general, the increasing trends of the annual frequency of days with $T_{\max } \geq 36^{0} \mathrm{C}$ are also statistically significant at about $50 \%$ stations up to $95-99 \%$ level of significance.

Table 1: Seasonal and annual trends of the frequency of days with $T_{\max } \geq 36^{\circ} \mathrm{C}$ over Bangladesh during 19812016

\begin{tabular}{|c|c|c|c|c|c|c|}
\hline \multirow[t]{2}{*}{ Stations } & \multicolumn{3}{|c|}{ Seasonal trends (Pre-monsoon) } & \multicolumn{3}{|c|}{ Annual trends } \\
\hline & (day/year) & $\mathrm{R}^{2}$ & F-Test & (day/year) & $\mathrm{R}^{2}$ & F-Test \\
\hline Dhaka & 0.042 & 0.001 & 0.034034 & 0.101 & 0.007 & 0.239678 \\
\hline Mymensingh & -0.069 & 0.061 & 2.208733 & -0.042 & 0.019 & 0.658512 \\
\hline Tangail & 0.127 & $0.190 * *$ & 7.975309 & 0.035 & $0.453 * *$ & 24.01645 \\
\hline Faridpur & 0.158 & 0.022 & 0.764826 & 0.241 & 0.046 & 1.639413 \\
\hline Madaripur & -0.094 & 0.009 & 0.308779 & -0.086 & 0.007 & 0.239678 \\
\hline Chittagong & 0.051 & 0.078 & 2.876356 & 0.067 & 0.089 & 3.321625 \\
\hline Sitakunda & 0.145 & $0.177^{*}$ & 7.312272 & 0.186 & $0.206^{* *}$ & 8.821159 \\
\hline Rangamati & 0.416 & $0.222 * *$ & 9.701799 & 0.438 & $0.209 * *$ & 8.983565 \\
\hline Cox's Bazar & 0.082 & $0.144^{*}$ & 5.719626 & 0.093 & $0.131 *$ & 5.125432 \\
\hline Sandwip & 0.07 & $0.180 * *$ & 7.463415 & 0.092 & $0.183 * *$ & 7.615667 \\
\hline Kutubdia & 0 & $2.00 \mathrm{E}-05$ & 0.00068 & -0.011 & 0.003 & 0.102307 \\
\hline Teknaf & -0.006 & 0.007 & 0.239678 & -0.013 & 0.023 & 0.800409 \\
\hline M. Court & 0.376 & $0.349 * *$ & 18.22734 & 0.486 & $0.420 * *$ & 24.62069 \\
\hline Chandpur & 0.261 & $0.323 * *$ & 16.22157 & 0.324 & $0.377 * *$ & 20.57464 \\
\hline Comilla & 0.074 & 0.050 & 1.789474 & 0.083 & 0.050 & 1.789474 \\
\hline Feni & 0.078 & 0.045 & 1.602094 & 0.072 & 0.041 & 1.453597 \\
\hline Hatiya & 0.058 & 0.092 & 3.444934 & 0.06 & 0.104 & 3.946429 \\
\hline Srimangal & -0.067 & 0.012 & 0.412955 & 0.02 & $0.192 * *$ & 7.841584 \\
\hline Sylhet & 0.127 & $0.198 * *$ & 8.394015 & 0.048 & $0.645 * *$ & 61.77465 \\
\hline Khulna & 0.493 & $0.184 * *$ & 7.666667 & 0.195 & $0.123^{*}$ & 4.768529 \\
\hline Satkhira & -0.067 & 0.002 & 0.068136 & 0.210 & 0.016 & 0.422764 \\
\hline Jessore & 0.419 & $0.096^{*}$ & 3.610619 & 0.750 & $0.223 * *$ & 9.758044 \\
\hline Chuadanga & -0.203 & 0.013 & 0.447822 & 0.048 & 0.000 & 0.000 \\
\hline Mongla & 0.816 & $0.302 * *$ & 14.7106 & 1.018 & $0.372 * *$ & 20.14013 \\
\hline Khepupara & 0.134 & $0.125 *$ & 4.857143 & 0.188 & $0.195 * *$ & 8.236025 \\
\hline Barisal & 0.159 & 0.088 & 3.280702 & 0.19 & $0.107 *$ & 4.073908 \\
\hline Patuakhali & 0.509 & $0.455 * *$ & 28.38532 & 0.586 & $0.504 * *$ & 34.54839 \\
\hline Bhola & 0.031 & 0.063 & 2.286019 & 0.037 & 0.011 & 0.37816 \\
\hline Rajshahi & 0.095 & 0.006 & 0.205231 & 0.628 & $0.166^{*}$ & 6.767386 \\
\hline Rangpur & -0.062 & 0.03 & 1.051546 & 0.003 & $6.00 \mathrm{E}-05$ & 0.00204 \\
\hline Dinajpur & -0.198 & 0.055 & 1.978836 & -0.114 & 0.017 & 0.587996 \\
\hline Ishurdi & 0.035 & 0.000 & 0.000 & 0.257 & 0.026 & 0.907598 \\
\hline Bogra & 0.012 & 0.000 & 0.000 & 0.219 & 0.058 & 2.093418 \\
\hline Syedpur & 0.022 & 0.000 & 0.000 & 0.040 & $0.453 * *$ & 19.87569 \\
\hline
\end{tabular}

The graphical representations of the seasonal and annual frequency of days with $T_{\max } \geq 36^{\circ} \mathrm{C}$ at the divisional stations of BMD are given in Figures 6(a-h) and 7(a-h) respectively. Figures 6(a-h) show that the seasonal frequency of days with $T_{\max } \geq 36^{\circ} \mathrm{C}$ has increasing trends at Dhaka, Rajshahi, Chittagong, Sylhet, Barisal and Khulna and the rates of increasing are $0.042,0.095,0.051,0.127,0.159$ and 0.493 day/year, respectively. The increasing rates of seasonal frequency of days with $T_{\max } \geq 36^{\circ} \mathrm{C}$ at Sylhet and Khulna are statistically at $99 \%$ level of significance. The seasonal frequency of days with $T_{\max } \geq 36^{\circ} \mathrm{C}$ has decreasing trends at Mymensingh and Rangpur at -0.069 and -0.062 day/year, respectively. Figures 7(a-h) show that the annual frequency of days with $T_{\max } \geq 36^{\circ} \mathrm{C}$ has increasing trends at Dhaka, Rangpur, Rajshahi, Chittagong, Sylhet, Barisal and Khulna with the rates of increasing are $0.101,0.003,0.628,0.067,0.311,0.190$ and 0.671 day/year, respectively. The increasing rates of annual frequency of days with $T_{\max } \geq 36^{\circ} \mathrm{C}$ at Rajshahi, Sylhet and Khulna are statistically 
at $99 \%$ level of significance. The annual frequency of days with $T_{\max } \geq 36^{\circ} \mathrm{C}$ has decreasing trends at Mymensingh at -0.042 day/year. This increase in the frequency of days with $T_{\max } \geq 36^{0} \mathrm{C}$ may be mainly due to the urbanization effects and increase in population along with their several activities.
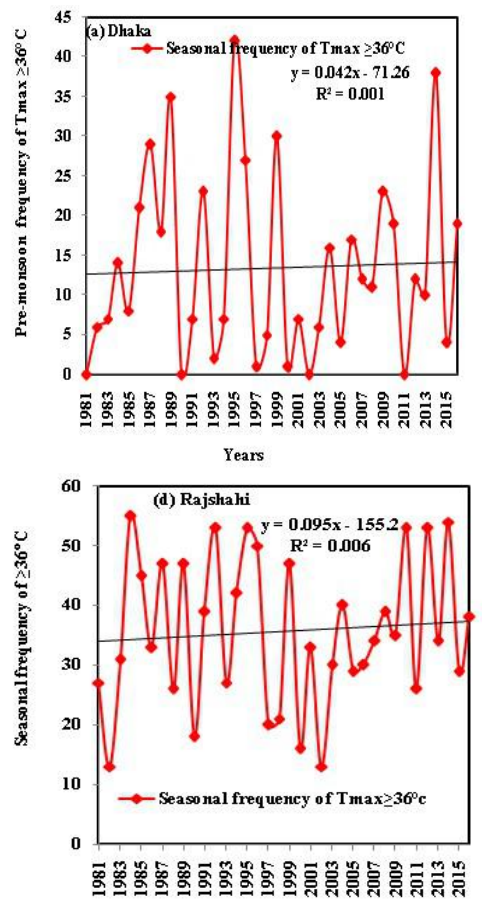

Yeras

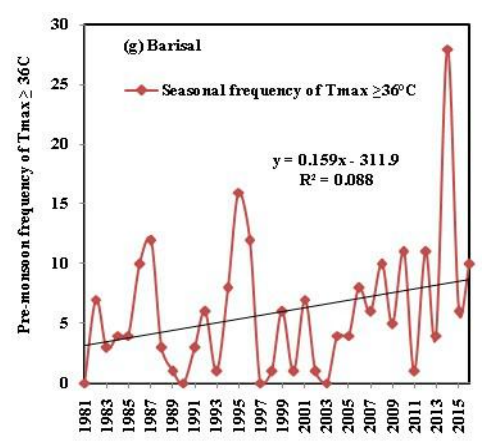

Years
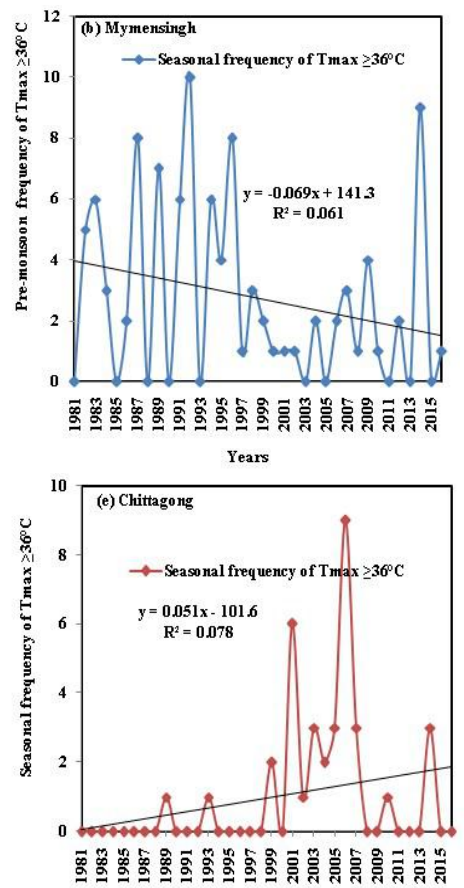

Years
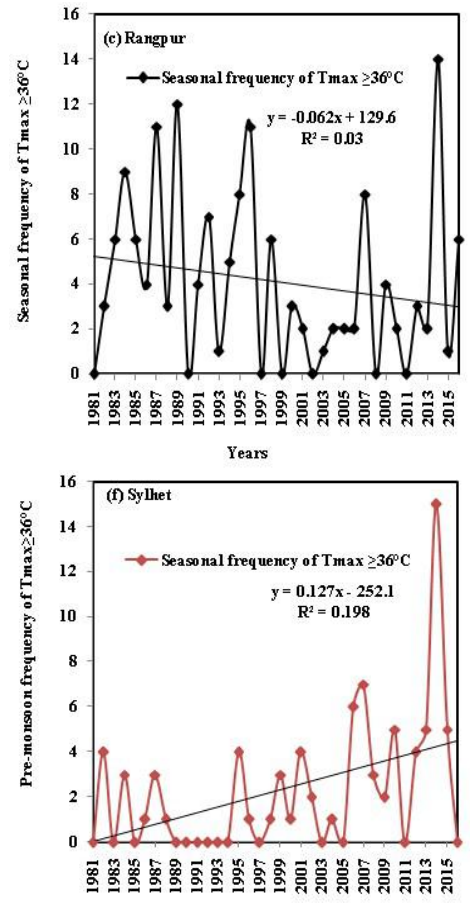

Years

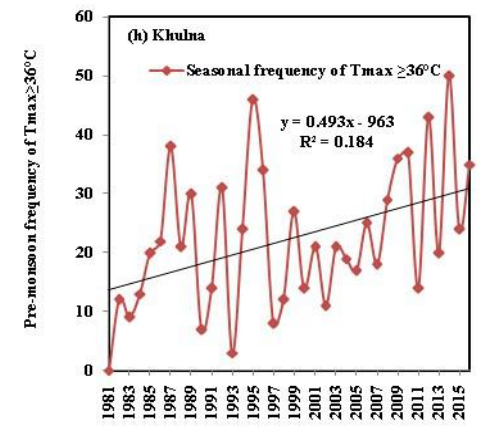

Years

Figure 6: Trend in seasonal frequency of days with $T_{\max } \geq 36^{\circ} \mathrm{C}$ at (a) Dhaka, (b) Mymensingh, (c) Rangpur, (d) Rajshahi, (e) Chittagong, (f) Sylhet, (g) Barisal and (h) Khulna during the pre-monsoon season of 1981-2016

\subsection{Distribution of the trends in seasonal and annual frequency of maximum temperature $\geq 36^{\circ} \mathrm{C}$ in Bangladesh}

The spatial distributions of the trends of seasonal and annual frequency of $T_{\max } \geq 36^{\circ} \mathrm{C}$ are shown in Figures 89 respectively. Both the figures show maximum trends of the frequency of $T_{\max } \geq 36^{0} \mathrm{C}$ over southwestern parts of the country. The seasonal and annual maximum trends are found to be 0.816 day/year and 1.02 day/year, respectively at Mongla. The seasonal trends of the frequency of $T_{\max } \geq 36^{0} \mathrm{C}$ is negative (i.e. decreasing trend) over Madaripur, Srimangal, Satkhira, Mymensingh, Chuadanga and northwestern part of the country. The Chittagong Hill tracts have the secondary maximum increasing trends of the frequency of $T_{\max } \geq$ $36^{\circ} \mathrm{C}$, having the order of 0.10-0.14 day/year (Figure 8). The annual frequency of $T_{\max } \geq 36^{\circ} \mathrm{C}$ has secondary maximum increasing trend over Rajshahi region having the increasing rates of the order of $0.20-0.70$ day/year (Figure 9); Chittagong Hill Tracts have third maximum increasing trends of $T_{\max } \geq 36^{0} \mathrm{C}$ with increasing rates of 0.20-0.40 day/year. The higher increasing trends of seasonal and annual $T_{\max } \geq 36^{\circ} \mathrm{C}$ over Chittagong Hill Tracts are due to the more deforestation over the region and that over the western part may be advection of higher maximum temperature from west-northwestern part of India. The annual frequency of $T_{\max } \geq 36^{0} \mathrm{C}$ has decreasing trends at Dinajpur, Mymensingh, Madaripur, Kutubdia and Teknaf. The higher increasing trends of 
annual frequency of $T_{\max } \geq 36^{\circ} \mathrm{C}$ indicate that maximum temperature also becomes $\geq 36^{\circ} \mathrm{C}$ during the southwest monsoon season.
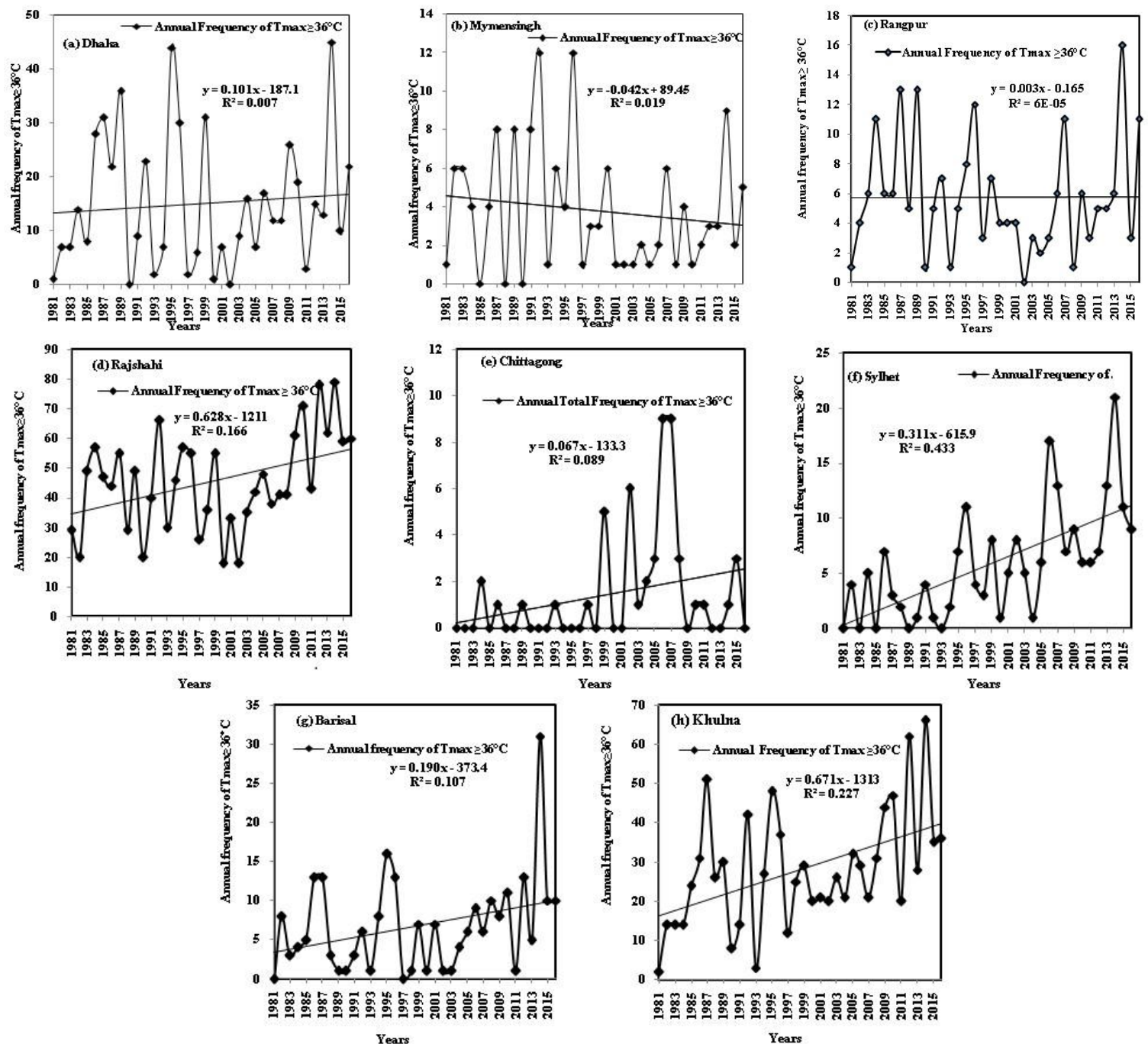

Figure 7: Trend in annual frequency of days with $T_{\max } \geq 36^{\circ} \mathrm{C}$ at (a) Dhaka, (b) Mymensingh, (c) Rangpur, (d) Rajshahi, (e) Chittagong, (f) Sylhet, (g) Barisal and (h) Khulna during the pre-monsoon season of 1981-2016

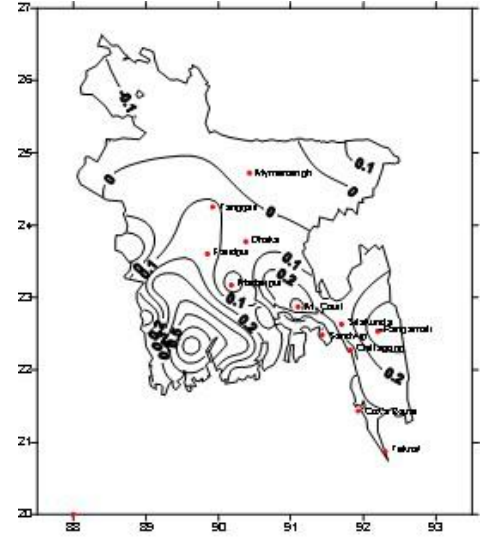

Figure 8: Spatial distribution of the trends of seasonal frequency of days with $T_{\max } \geq$ $36^{\circ} \mathrm{C}$ during 1981-2016

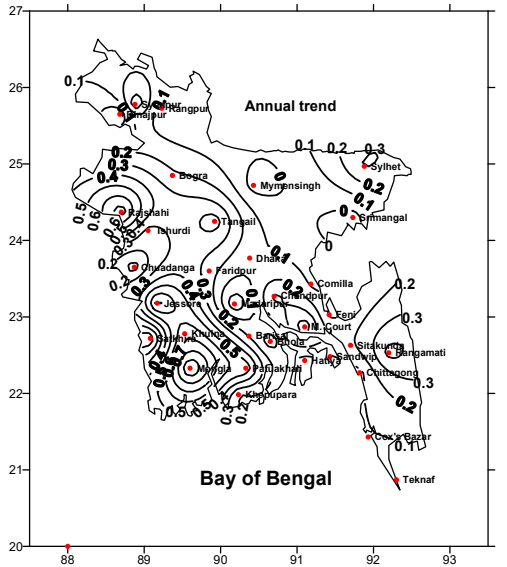

Figure 9: Spatial distribution of the trends of annual frequency of days with $T_{\max } \geq$ $36^{\circ} \mathrm{C}$ during 1981-2016 
From the above discussion, it is apparent that the seasonal and annual frequency of $T_{\max } \geq 36^{\circ} \mathrm{C}$ have increasing trends in Bangladesh except a very few places, having the highest increasing trends over southwestern part of the country with increasing rates of 0.816 and 1.02 day/year respectively at Mongla. The higher increasing trend of annual frequency of $T_{\max } \geq 36^{\circ} \mathrm{C}$ is due to the fact that maximum temperature also attains $\geq 36^{\circ} \mathrm{C}$ during the southwest monsoon season. If these trends continue, heat waves are likely to be more prominent over the western part of Bangladesh as well as Chittagong Hill Tracts.

\subsection{Seasonal and annual frequency of days with maximum temperature $\geq 38^{\circ} \mathrm{C}$ and their trends in Bangladesh}

The seasonal (March-May) and annual frequencies of days with maximum temperature $\geq 38^{\circ} \mathrm{C}$ have been computed using the $T_{\max }$ data for the period 1981-2016. In the annual frequencies of days with maximum temperature $\geq 38^{\circ} \mathrm{C}, T_{\max }$ of pre-monsoon and monsoon seasons contributes mainly; the post-monsoon and winter seasons do not have any contribution in the heat waves of Bangladesh.

The highest frequency of days $T_{\max } \geq 38^{\circ} \mathrm{C}$ in the pre-monsoon season during the period 1981-2016 is shown in Figure 10, which shows the highest frequencies of days with $T_{\max } \geq 38^{\circ} \mathrm{C}$ in 2014 are found in 15 stations out of 34 stations i.e. $44.12 \%$ stations but the maximum highest frequencies of days with $T_{\max } \geq 38^{0} \mathrm{C}$ are 43 , 41, 39 and 55 days at Rajshahi in 1992, Chuadanga in 1995, Ishurdi in 1995 and Jessore in 2014, respectively. In 2014 , the heat waves $\left(T_{\max } \geq 38^{\circ} \mathrm{C}\right)$ persisted for many days at many places as is evident from Figure 10 . The highest frequencies of days with $T_{\max } \geq 38^{\circ} \mathrm{C}$ are found to occur in the western Bangladesh and there are no days with $T_{\max } \geq 38^{\circ} \mathrm{C}$ at Cox's Bazar, Kutubdia, Mymensingh, Sandwip and Sylhet and the frequency of $T_{\max } \geq 38^{\circ} \mathrm{C}$ in minimum in the eastern part of the country in the pre-monsoon season.

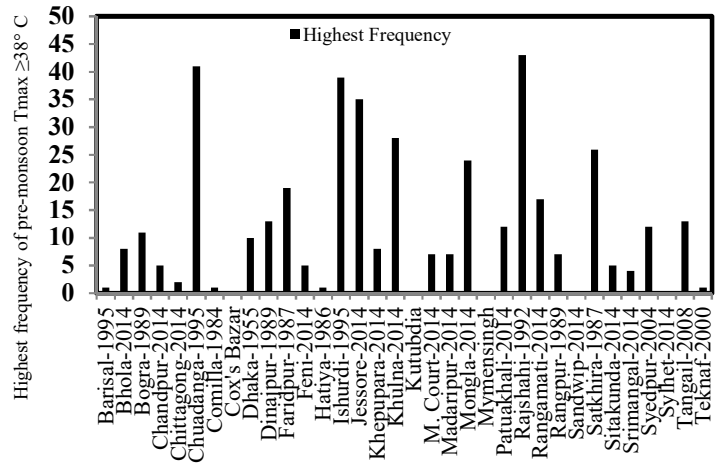

Stations of BMD

Figure 10: Highest pre-monsoon frequency of days with $T_{\max } \geq 38^{\circ} \mathrm{C}$ during 1981-2016 in Bangladesh

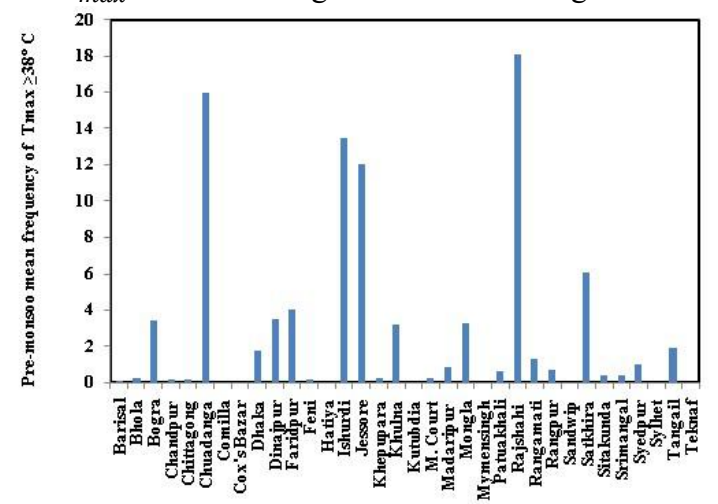

Stations of BMD

Figure 12: Mean pre-monsoon frequency of days with $T_{\max } \geq 38^{\circ} \mathrm{C}$ during 1981-2016 in Bangladesh

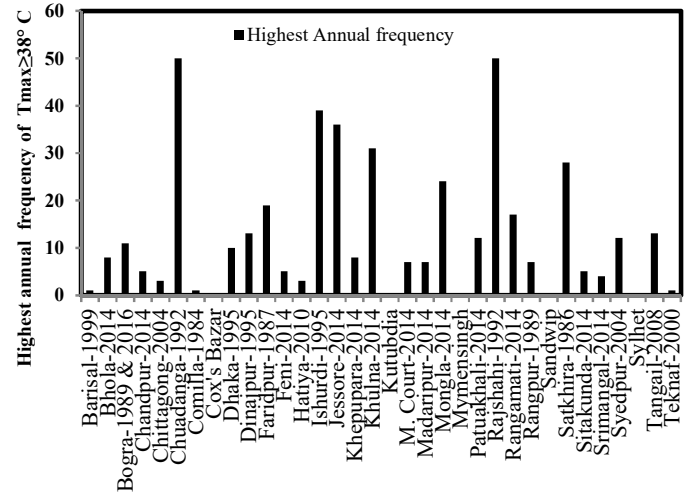

Stations of BMD

Figure 11: Highest annual frequency of days with $T_{\max } \geq 38^{\circ} \mathrm{C}$ in Bangladesh

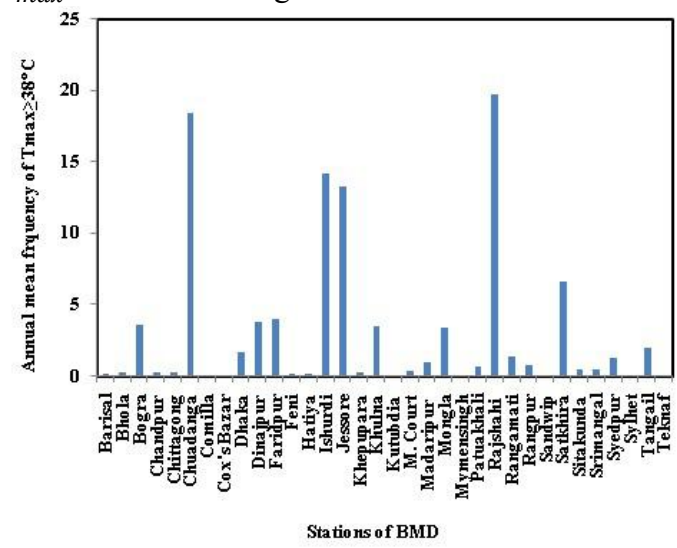

Figure 13: Mean annual frequency of days with $T_{\max } \geq 38^{\circ} \mathrm{C}$ in Bangladesh during 1981-2016

Figure 11 shows the highest annual frequency of days with $T_{\max } \geq 38^{\circ} \mathrm{C}$ during 1981-2016 in Bangladesh. It is seen that highest annual frequencies of days with $T_{\max } \geq 38^{\circ} \mathrm{C}$ are in 2014 at 13 (38.24\%) out of 34 stations during the period 1981-2016, indicating that the heat waves are found to spread in relatively many places in 
Bangladesh. In 2014, $T_{\max } \geq 38^{\circ} \mathrm{C}$ is found to exist annually for many days in western part of Bangladesh in comparison to the eastern and coastal region of the country. $T_{\max } \geq 38^{\circ} \mathrm{C}$ is found to prevail annually for 50 days at Rajshahi and Chuadanga in 1992, 39 days at Ishurdi in 1995, 36 days at Jessore in 2014, 31 day at Khulna in 2014 (Figure 11). This prevailing of $T_{\max } \geq 38^{\circ} \mathrm{C}$ annually for many days indicates moderate to severe heat waves and is detrimental for the production of crops, vegetables and fruits as well as for the health of human being, cattle and other domestic and wild animals.

Figure 12 shows the mean pre-monsoon frequency of days with $T_{\max } \geq 38^{\circ} \mathrm{C}$ during 1981-2016 in Bangladesh and reveals that higher seasonal mean days of $T_{\max } \geq 38^{\circ} \mathrm{C}$ are less than that of $T_{\max } \geq 38^{\circ} \mathrm{C}$ and are 18.11 , 16.00, 13.51 and 12.09 days at Rajshahi, Chuadanga, Ishurdi and Jessore respectively. The mean annual frequency of days $T_{\max } \geq 38^{\circ} \mathrm{C}$ during 1981-2016 in Bangladesh is given in Figure 13, which shows that the higher annual mean days with $T_{\max } \geq 38^{\circ} \mathrm{C}$ are $19.72,18.39,14.17$ and 13.25 at Rajshahi, Chuadanga, Ishurdi and Jessore, respectively. It is also evident from the figures that the western part of the country has the higher seasonal and annual days with $T_{\max } \geq 38^{\circ} \mathrm{C}$ extending to Tangail-Dhaka-Madaripur-Faridpur region, the highest frequency is at Rajshahi.

Table 2: Seasonal and annual trends of the frequency of days with $T_{\max } \geq 38^{\circ} \mathrm{C}$ over Bangladesh during 19812016

\begin{tabular}{|c|c|c|c|c|c|c|}
\hline Stations & Annual trend & $\mathrm{R}^{2}$ & F-Test & Seasonal trend & $\mathrm{R}^{2}$ & F-test \\
\hline Mymensingh & $\mathrm{n}$ & $\mathrm{n}$ & $\mathrm{n}$ & $\mathrm{n}$ & 0 & 0 \\
\hline Tangail & -0.077 & 0.057 & 2.055143 & -0.078 & 0.059 & 2.131775 \\
\hline Faridpur & -0.062 & 0.017 & 0.587996 & -0.059 & 0.016 & 0.552846 \\
\hline Madaripur & -0.021 & 0.021 & 0.729316 & -0.02 & 0.021 & 0.729316 \\
\hline Chittagong & 0.017 & 0.072 & 2.637931 & 0.014 & 0.088 & 3.280702 \\
\hline Sitakunda & 0.03 & 0.117 & $4.505096^{*}$ & 0.03 & 0.119 & $4.592509^{*}$ \\
\hline Rangamati & 0.079 & 0.07 & 2.55914 & 0.073 & 0.063 & 2.286019 \\
\hline Cox's Bazar & $\mathrm{n}$ & $\mathrm{n}$ & $\mathrm{n}$ & $\mathrm{n}$ & $\mathrm{n}$ & $\mathrm{n}$ \\
\hline Sandwip & $\mathrm{n}$ & $\mathrm{n}$ & $\mathrm{n}$ & $\mathrm{n}$ & $\mathrm{n}$ & $\mathrm{n}$ \\
\hline Kutubdia & $\mathrm{n}$ & $\mathrm{n}$ & $\mathrm{n}$ & $\mathrm{n}$ & $\mathrm{n}$ & $\mathrm{n}$ \\
\hline Teknaf & -0.003 & 0.03 & 1.051546 & -0.003 & 0.03 & 1.051546 \\
\hline M. Court & 0.032 & 0.084 & 3.117904 & 0.035 & 0.098 & 3.694013 \\
\hline Chandpur & 0.261 & 0.323 & $16.22157 * *$ & 0.019 & 0.063 & 2.286019 \\
\hline Comilla & -0.003 & 0.055 & 1.978836 & -0.003 & 0.055 & 1.978836 \\
\hline Feni & 0.024 & 0.092 & 3.444934 & 0.024 & 0.092 & 3.444934 \\
\hline Hatiya & 0.005 & 0.013 & 0.447822 & -0.003 & 0.041 & 1.453597 \\
\hline Srimangal & -0.014 & 0.019 & 0.658512 & -0.008 & 0.006 & 0.205231 \\
\hline Sylhet & -0.003 & 0.03 & 1.051546 & -0.003 & 0.03 & 1.051546 \\
\hline Khulna & 0.195 & 0.123 & $4.768529^{*}$ & 0.161 & 0.109 & $4.159371^{*}$ \\
\hline Satkhira & -0.094 & 0.017 & 0.587996 & -0.067 & 0.01 & 0.343434 \\
\hline Jessore & 0.212 & 0.06 & 2.170213 & 0.12 & 0.022 & 0.764826 \\
\hline Chuadanga & -0.172 & 0.013 & 0.447822 & -0.218 & 0.025 & 0.871795 \\
\hline Mongla & 0.242 & 0.163 & $6.621266^{*}$ & 0.225 & 0.141 & $5.580908^{*}$ \\
\hline Khepupara & 0.031 & 0.063 & 2.286019 & 0.031 & 0.063 & 2.286019 \\
\hline Barisal & -0.009 & 0.075 & 2.756757 & -0.004 & 0.022 & 0.764826 \\
\hline Patuakhali & 0.067 & 0.123 & $4.768529 *$ & 0.064 & 0.111 & 4.245219 \\
\hline Bhola & 0.031 & 0.063 & 2.286019 & 0.031 & 0.063 & 2.286019 \\
\hline Rajshahi & 0.027 & 0 & 0 & 0.013 & 0 & 0 \\
\hline Rangpur & -0.039 & 0.082 & 3.037037 & -0.035 & 0.068 & 2.480687 \\
\hline Dinajpur & -0.08 & 0.049 & 1.75184 & -0.087 & 0.058 & 2.093418 \\
\hline Ishurdi & -0.094 & 0.009 & 0.308779 & -0.067 & 0.005 & 0.170854 \\
\hline Bogra & 0 & $2.00 \mathrm{E}-06$ & $6.80 \mathrm{E}-05$ & -0.009 & 0 & 0 \\
\hline Syedpur & -0.047 & 0.02 & 0.693878 & -0.032 & 0.01 & 0.343434 \\
\hline
\end{tabular}

The temporal variations of the seasonal and annual frequency of days with $T_{\max } \geq 38^{\circ} \mathrm{C}$ have been considered to find out the trends in days with $T_{\max } \geq 38^{\circ} \mathrm{C}$; the results are given in Table 2 . The table shows that the seasonal frequency of days with $T_{\max } \geq 38^{0} \mathrm{C}$ has decreasing trends at 16 out of 31 stations $(51.61 \%)$ with the highest decreasing rate of -0.067 day/year at Satkhira and Ishurdi; whereas the seasonal frequency of days with $T_{\max } \geq 38^{\circ} \mathrm{C}$ has increasing trends at 15 stations $(48.39 \%)$. 


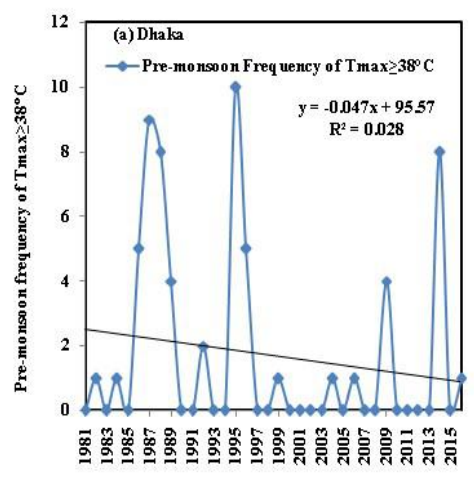

Years

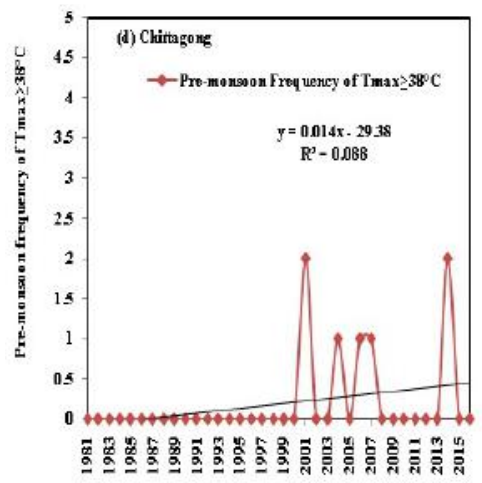

Years
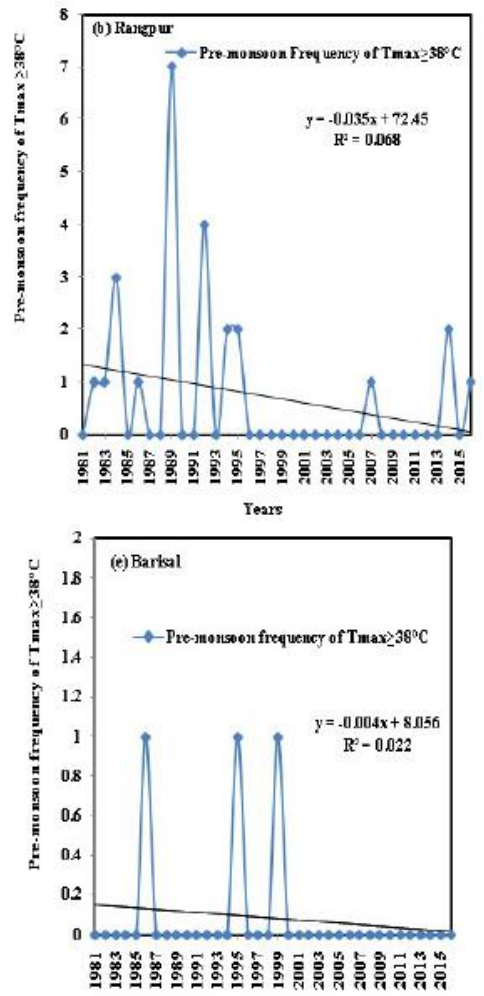

Years

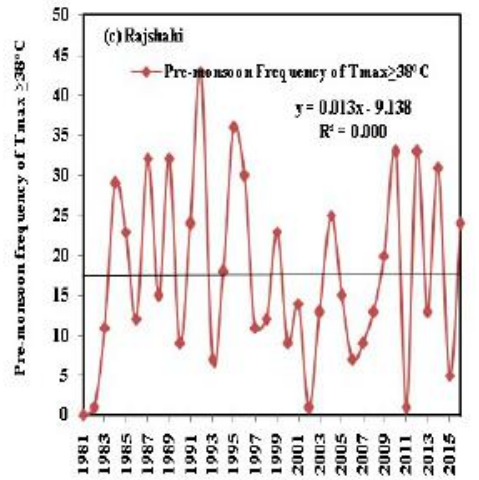

Years

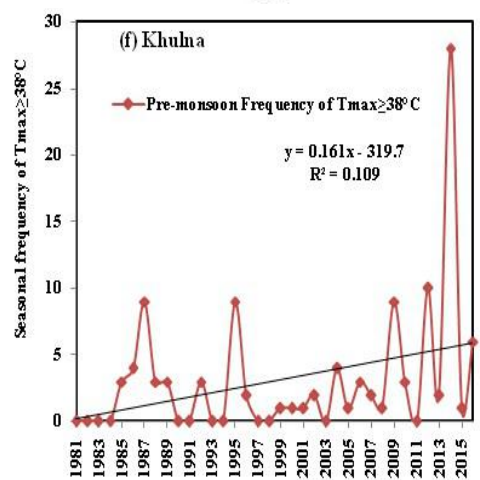

Figure 14: Trend in annual frequency of days with $T_{\max } \geq 38^{\circ} \mathrm{C}$ at (a) Dhaka, (b) Mymensingh, (c) Rangpur, (d) Rajshahi, (e) Chittagong, (f) Sylhet, (g) Barisal and (h) Khulna during the pre-monsoon season of 1981-2016
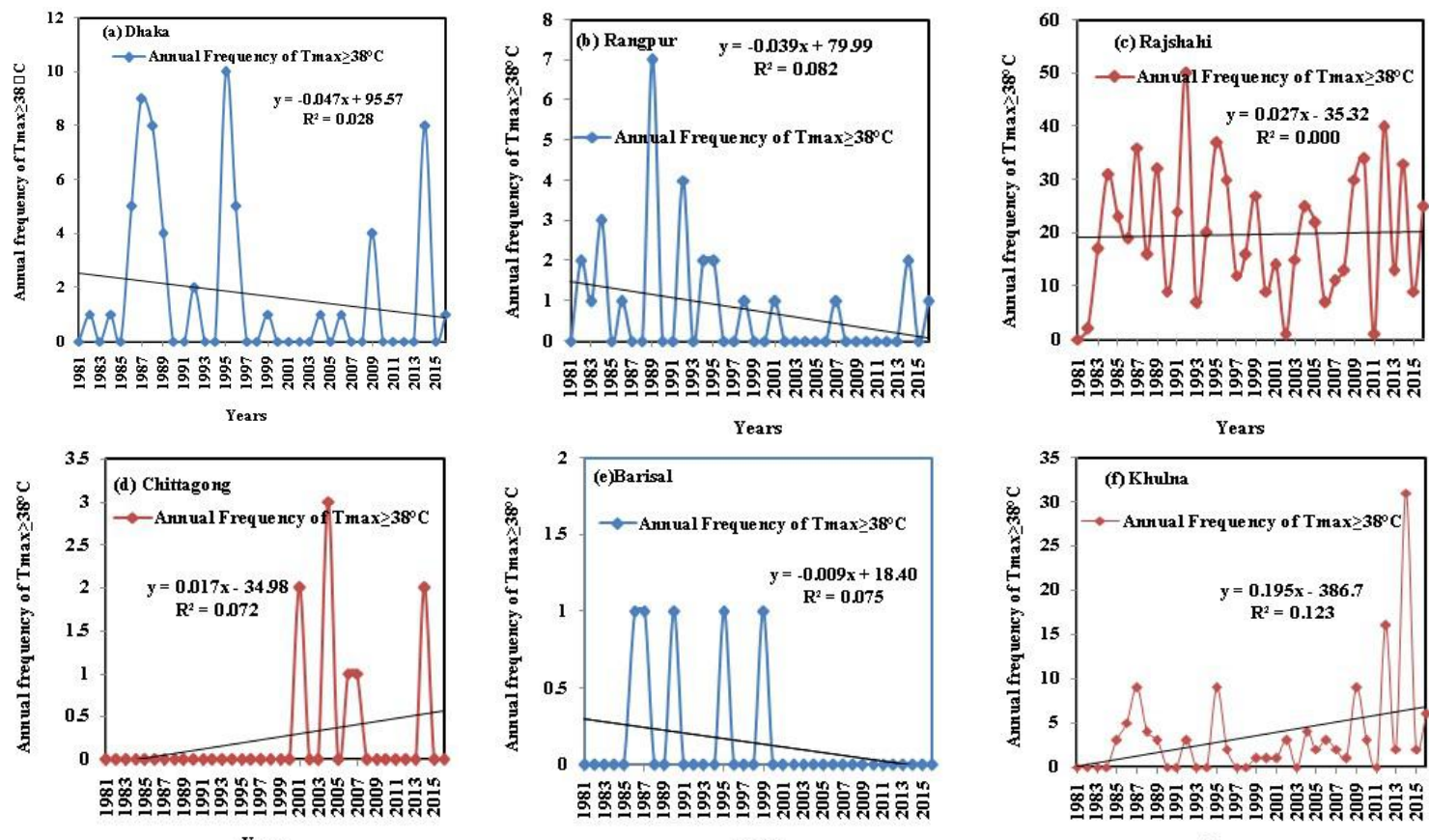

Years

Figure 15: Trend in annual frequency of days with $T_{\max } \geq 38^{\circ} \mathrm{C}$ at (a) Dhaka, (b) Mymensingh, (c) Rangpur, (d) Rajshahi, (e) Chittagong, (f) Sylhet, (g) Barisal and (h) Khulna during 1981-2016

The increasing rates of seasonal frequency of days with $T_{\max } \geq 38^{\circ} \mathrm{C}$ are statistically significant at some stations up to $95-99 \%$ level of significance. While the annual frequency of days with $T_{\max } \geq 38^{\circ} \mathrm{C}$ has 
increasing trends at 14 out of 31 stations (45.16\%) with the highest increasing rate of +0.261 day/year at Chandpur and the second highest increasing rate of +0.242 day/year at Mongla. These two rates are highly significant at $95 \%$ and $99 \%$ level of significance, respectively. It is also found that the annual frequency of days with $T_{\max } \geq 38^{\circ} \mathrm{C}$ has decreasing trends at 14 stations $(45.16 \%)$ out of 31 stations with highest decreasing trend of -0.172 day/year at Chuadanga. In general, some of the increasing trends of the annual frequency of days with $T_{\text {max }} \geq 38^{\circ} \mathrm{C}$ are also statistically significant up to $95-99 \%$ level of significance.

The graphical representations of the seasonal and annual frequency of $T_{\max } \geq 38^{\circ} \mathrm{C}$ at the divisional stations of BMD are given in Figures 14(a-f) and 15(a-f) respectively except Mymensingh and Sylhet where there is no $T_{\max } \geq 38^{\circ} \mathrm{C}$. Figures $14(\mathrm{a}-\mathrm{f})$ shows that the pre-monsoon frequency of days with $T_{\max } \geq 38^{\circ} \mathrm{C}$ has increasing trends at Rajshahi, Chittagong, and Khulna and the rates of increasing are $0.013,0.014$ and 0.161 day/year, respectively. The increasing rate of seasonal frequency of $T_{\max } \geq 38^{\circ} \mathrm{C}$ at Khulna is statistically at $95 \%$ level of significance. The seasonal frequency of $T_{\text {max }} \geq 38^{\circ} \mathrm{C}$ has decreasing trends at Dhaka, Rangpur, and Barisal at $-0.035,-0.004$ and -0.047 day/year, respectively. Figures $15(\mathrm{a}-\mathrm{f})$ shows that the annual frequency of days with $T_{\max } \geq 38^{\circ} \mathrm{C}$ has also increasing trends at has increasing trends at Rajshahi, Chittagong, and Khulna and the rates of increasing are $0.027,0.017$ and 0.195 day/year, respectively. The increasing rate of annual frequency of days with $T_{\max } \geq 38^{\circ} \mathrm{C}$ at Khulna is statistically at $99 \%$ level of significance. The annual frequency of days with $T_{\max } \geq 38^{\circ} \mathrm{C}$ has decreasing trends at Dhaka, Rangpur, and Barisal at the rates of $-0.047,-0.039$, and -0.009 day/year, respectively. This increase in the frequency of days with $T_{\max } \geq 38^{0} \mathrm{C}$ may be mainly due to the urbanization effects and increase in population along with their several activities. It is seen that seasonal and annual frequency of days with $T_{\max } \geq 38^{\circ} \mathrm{C}$ at Rajshahi and Khulna are much higher than the other divisional stations and are persisting for 5 days or more.

\subsection{Distribution of the trends in seasonal and annual frequency of maximum temperature $\geq 38^{\circ} \mathrm{C}$ in Bangladesh}

The distributions of the trends of seasonal (March-May) and annual frequency of $T_{\max } \geq 38^{0} \mathrm{C}$, representing moderate to severe heat waves, are shown in Figures 16(a-b) respectively. Both the figures indicate almost the same patterns of distribution of the trends of pre-monsoon and annual frequency of days with $T_{\max } \geq 38^{\circ} \mathrm{C}$ and reveal that the moderate to severe heat waves occur with increasing trends in the west-southwestern part of Bangladesh, having the maximum increasing trend over Khulna-Satkhira-Mongla region. The pre-monsoon frequency of days with $T_{\max } \geq 38^{\circ} \mathrm{C}$ has also increasing trend over Chuadanga-Ishurdi region. Heat waves of moderate to severe intensity do not extend over northern and eastern parts of the country except Rangamati region where increasing trends exist. Decreasing trends of pre-monsoon and annual frequency of days with $T_{\max } \geq 38^{\circ} \mathrm{C}$ are found in the Tangail-Dhaka-Faridpur region.
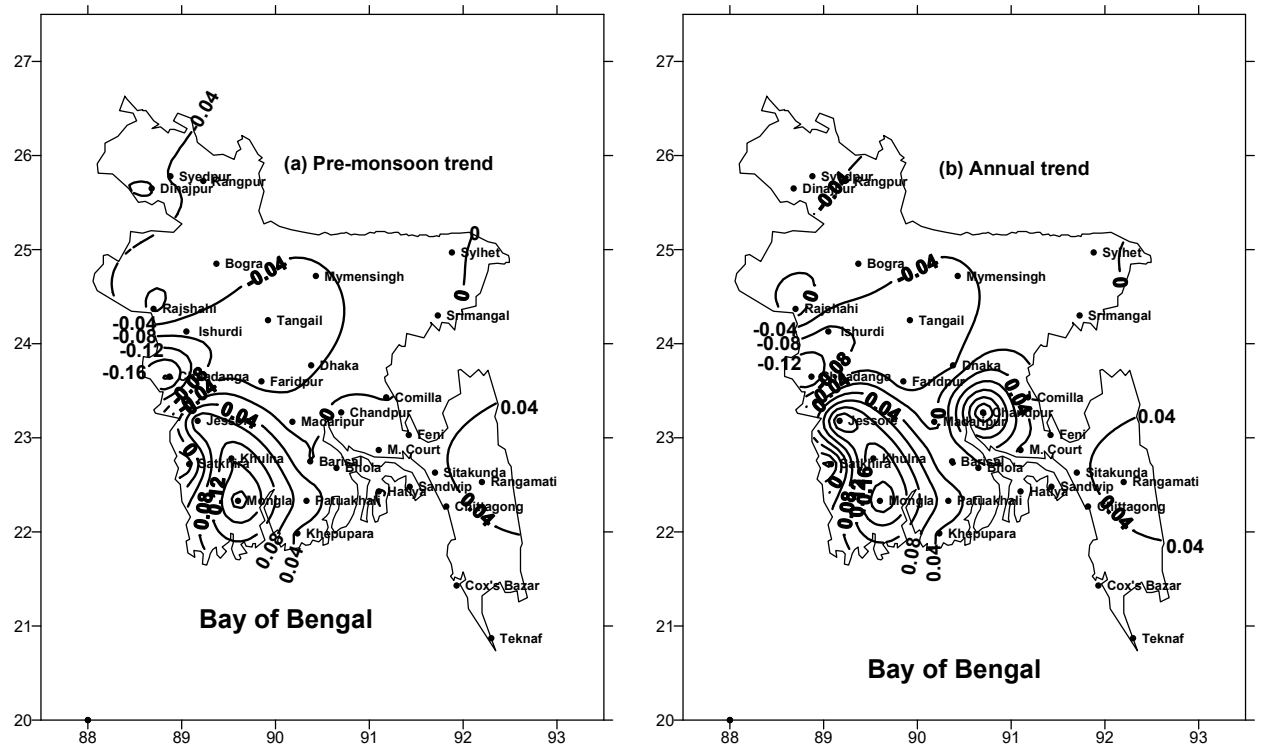

Figure 16: Spatial distribution of trends of (a) seasonal and (b) annual frequency of days with $T_{\max } \geq 38^{\circ} \mathrm{C}$ in Bangladesh during 1981-2016 
During the period 1981-2016, heat waves were severe and prominent in the recent year 2014 and this year has been considered for extensive investigation of the tropospheric conditions associated with heat waves.

\subsubsection{Heat waves in respect of maximum temperature and normal}

According to BMD, heat wave starts when $T_{\max } \geq 36^{\circ} \mathrm{C}$. Based on this, the maximum temperature at 34 stations in Bangladesh has been analyzed for the period 1981-2016 and found that the frequencies of days with $T_{\max } \geq 36^{\circ} \mathrm{C}$ and $\geq 38^{\circ} \mathrm{C}$ for the period $2001-2016$ have been found maximum in most places over Bangladesh in the year 2014 and heat waves are found to prevail for many days and spread over more places over the country. The temporal variation of the anomaly of $T_{\max }$ with respect to the normal of the period 1981-2010 have been analyzed over some stations in western part of Bangladesh and one example is given in Figure 17. All the figures show that the maximum temperature during March through May 2014 have been above $4^{\circ} \mathrm{C}$ to about 12 $14^{\circ} \mathrm{C}$ above normal for several days in western and northwestern Bangladesh, indicating mild to severe heat waves in the country. Maximum temperature is found below $4^{\circ} \mathrm{C}$ than normal or below normal in the beginning of March and at the end of May in 2014. The maximum temperature below $4^{\circ} \mathrm{C}$ than normal or below normal in the beginning of March may be due to the influence of winter and that at the end of May 2014 is due to the excessive rainfall prior to the onset of monsoon in the country (Figure 18).

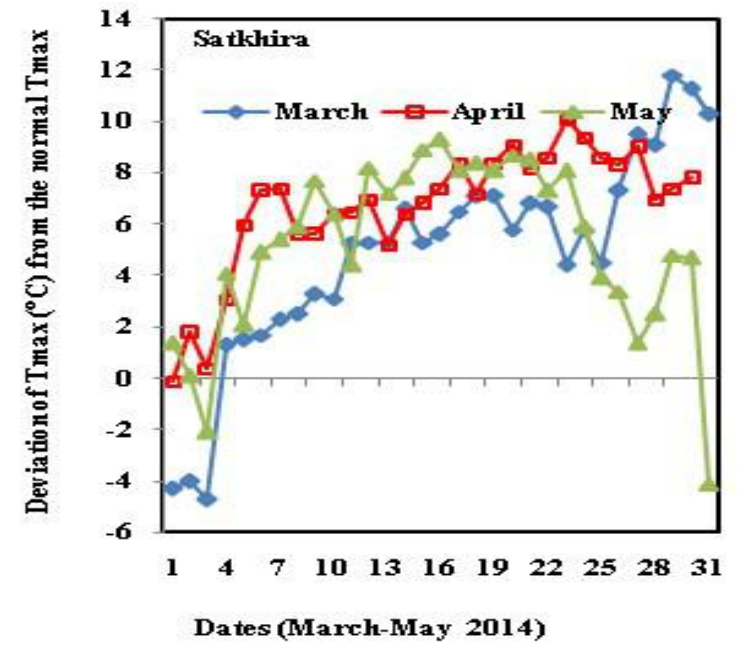

Figure 17: Comparison of maximum temperature in 2014 with normal $T_{\max }$

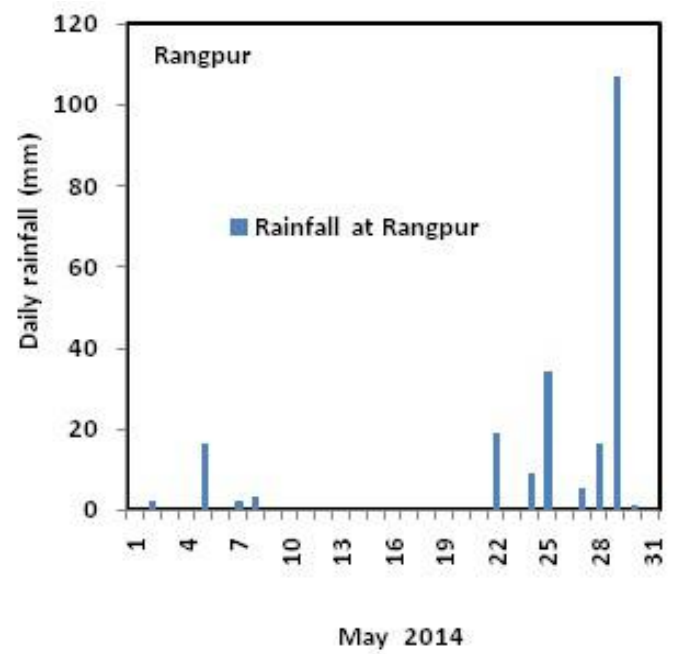

Figure 18: Temporal variation of rainfall at Rangpur in May 2014

\subsubsection{Direction of propagation of Heat Waves in Bangladesh}

The large-scale distribution of daily maximum temperature for the months of March-May 2014, the year of heat waves, have been prepared form NCEP Reanalysis data and examined critically to find out the causes of heat waves in Bangladesh. The distribution is shown, as for example, in Figure 19(a) and 19(b) for 21 April 2014 based on NCEP/NCAR Reanalysis and 21 May 2014 based on actual record of BMD. It has been found that the heat waves are generated over India, especially in the central India and is advected into Bangladesh raising the maximum temperature to $\geq 36^{\circ} \mathrm{C}$ due to the westerly/northwesterly wind. The primary centre of maximum temperature surrounding the country lies over India extended to West Bengal and adjoining Bangladesh. The whole India is found to come under the grip of heat waves. On $21 \mathrm{April} 2014$, a ridge of high $T_{\max }$ of $43^{\circ} \mathrm{C}$ is penetrated from the west towards the east across Kushtia-Chuadanga on 21 April 2014 as can be seen from the Figure 19(b). A secondary maximum of $T_{\max }$ is found over Chittagong Hill Tracts on the dates of heat waves. It is therefore apparent that the heat waves enter Bangladesh from the west due to the advection of higher maximum temperature.

\subsubsection{Distribution of Mild-Severe and Moderate-Severe Heat Waves Days during Pre- monsoon season in Bangladesh}

The spatial distributions of the pre-monsoon and annual frequency of days with $T_{\max } \geq 36^{0} \mathrm{C}$ and $T_{\max } \geq 38^{\circ} \mathrm{C}$ in 2014 over Bangladesh are given in Figures 20(a-b) and 21(a-b) respectively. The distribution patterns of the figures are almost the same, having maximum frequency over the western part of the country decreasing northeastwards, secondary maximum frequency over Chittagong Hill Tracts and minimum frequency over 
northern part of Bangladesh. In 2014, there have been 54-55 days with $T_{\max } \geq 36^{\circ} \mathrm{C}$ and 31-35 days with $T_{\text {max }} \geq 38^{\circ} \mathrm{C}$ in the pre-monsoon season in Jessore-Chuadanga region and these days indicate the heat waves of mild-severe and moderate-severe intensity (Figures 20a and 20b). Annually, there have been about 69-79 days with $T_{\max } \geq 36^{\circ} \mathrm{C}$ and $35-36$ days with $T_{\max } \geq 38^{\circ} \mathrm{C}$ in the western part of the country in 2014 (Figures 21a and $21 \mathrm{~b}$ ). From the patterns of the figures, it is apparent that the heat waves extend from west to east up to about central Bangladesh and a separate area of heat waves develops over the Chittagong Hill Tracts, the reason of which may be due to the diverging pattern of wind flows near the Chittagong Hill Tracts in the year of heat waves. Heat waves are absent along the region Sandwip-M.Court-Feni-Comilla region.
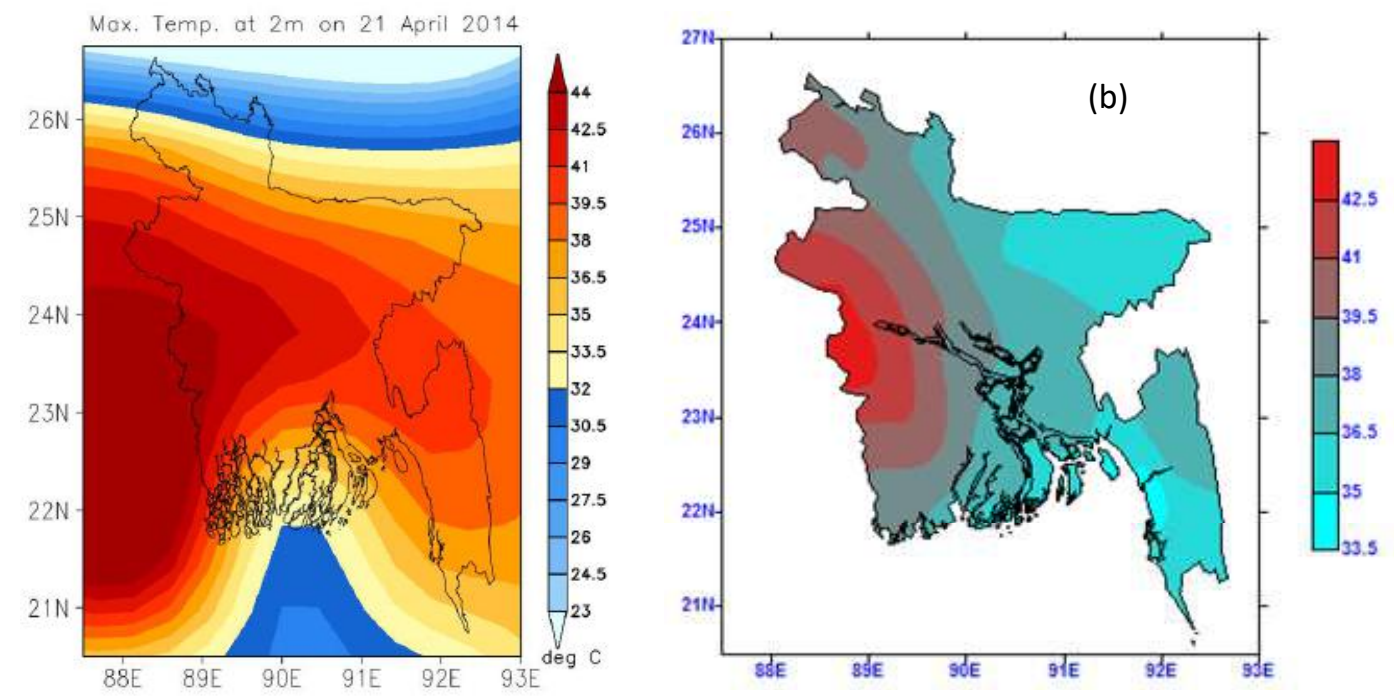

Figure 19: Distribution of $T_{\max }$ on (a) 21 April 2014 based on NCEP/NCAR Reanalysis 1 Project data (b) 21 May 2014 based on BMD data
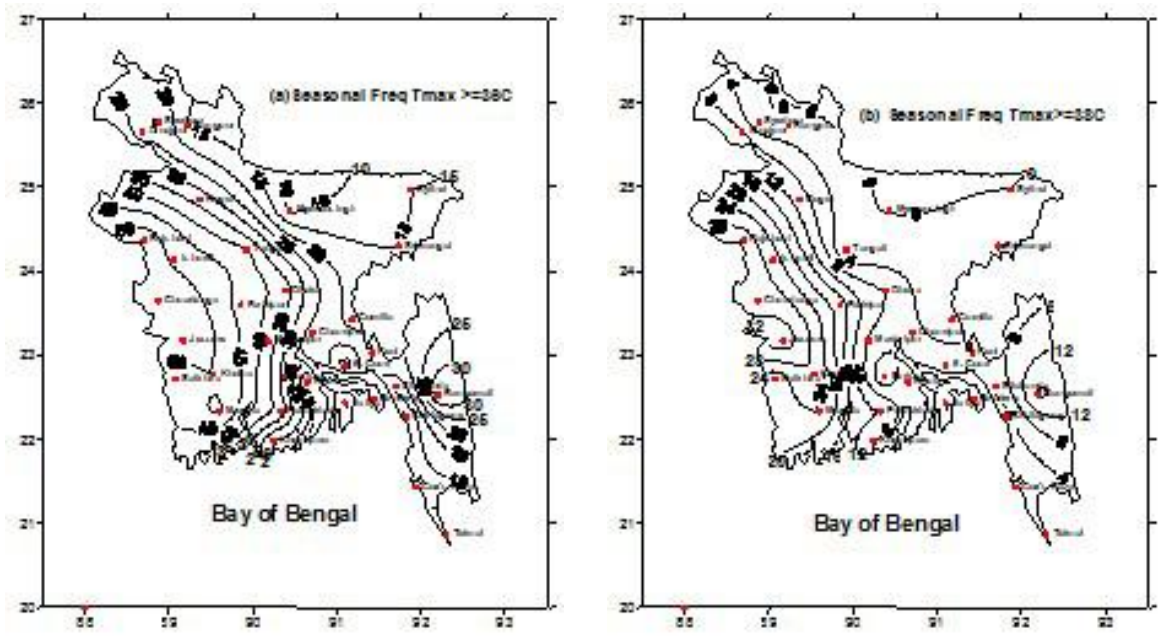

Figure 20: Frequency of days with (a) $T_{\max } \geq 36^{\circ} \mathrm{C}$ and (b) $T_{\max } \geq 38^{\circ} \mathrm{C}$ in 2014 during the pre-monsoon season in Bangladesh

\subsection{Large Scale distribution of sea level pressure}

The large-scale distribution of daily mean sea level pressure (MSLP) over Bangladesh and surrounding countries, obtained from NCEP Reanalysis for the period March-May of 2014 have been analyzed; some results are given in Figures 22(a-b) for 2014. In 2014, the central-northern part of India, Bangladesh and sometimes the Bay of Bengal are found to be under the influence of the sub-tropical high pressure on most of the days when $T_{\max }$ is higher with a very small low-pressure area near Bangladesh or adjoining West Bengal. As a result, convergence of wind flow has been absent because of the influence of high pressure and rainfall has been rare over Bangladesh [Figures 22 (a-b)]. In May 2014, narrow low-pressure area is sometimes found to develop over 
Sub-Himalayan West Bengal and adjoining Bihar but the whole Bangladesh is found to be under the influence of high pressure, indicating almost no rainfall condition in the country (Figure 22b). Moreover, influence of Sub-tropical high pressure (STHP) is also found in the east-southeastern Bangladesh, which may be responsible for the development of secondary higher $T_{\max }$ vis-a-vis a secondary heat wave area over Chittagong Hill Tracts or Rangamati region.
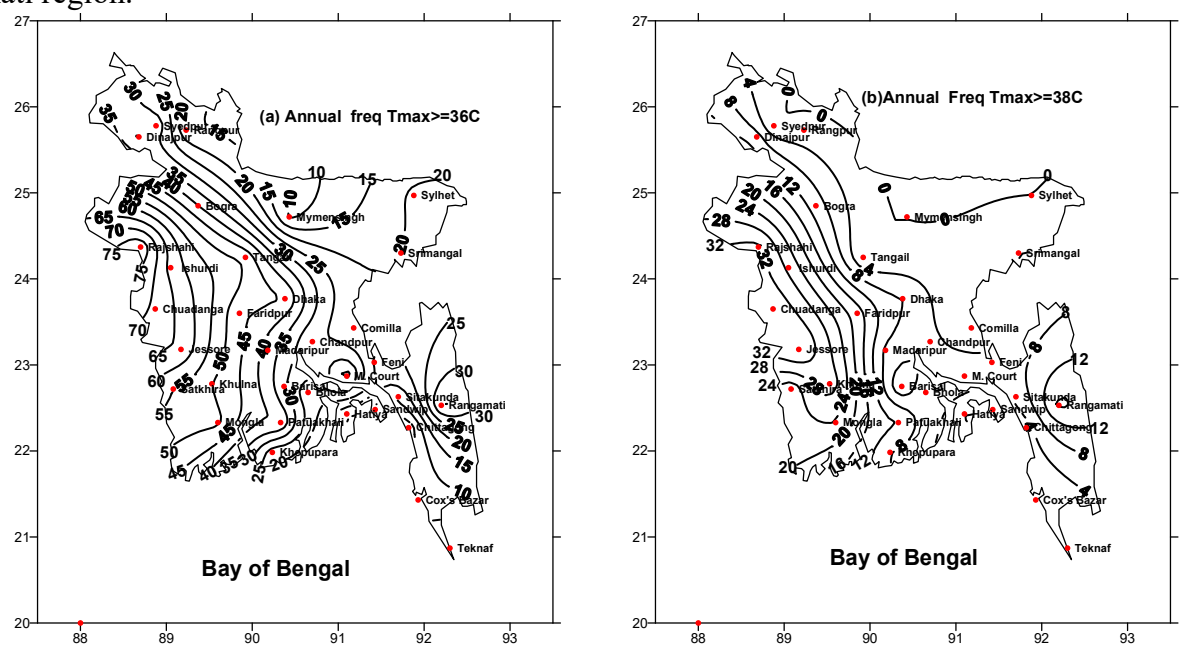

Figure 21: Annual days with (a) $T_{\max } \geq 36^{\circ} \mathrm{C}$ and (b) $T_{\max } \geq 38^{\circ} \mathrm{C}$ in 2014 during the pre-monsoon season in Bangladesh
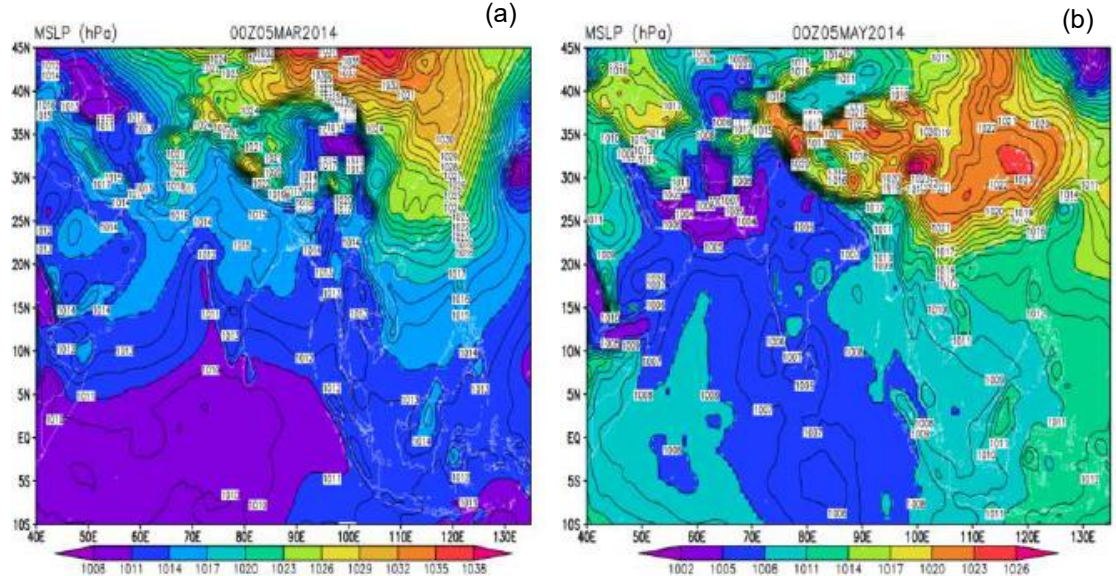

Figure 22: Large-scale distribution of mean sea level pressure at (a) 0000 UTC on 5 March 2014and (b) 0000 UTC on 5 May 2014

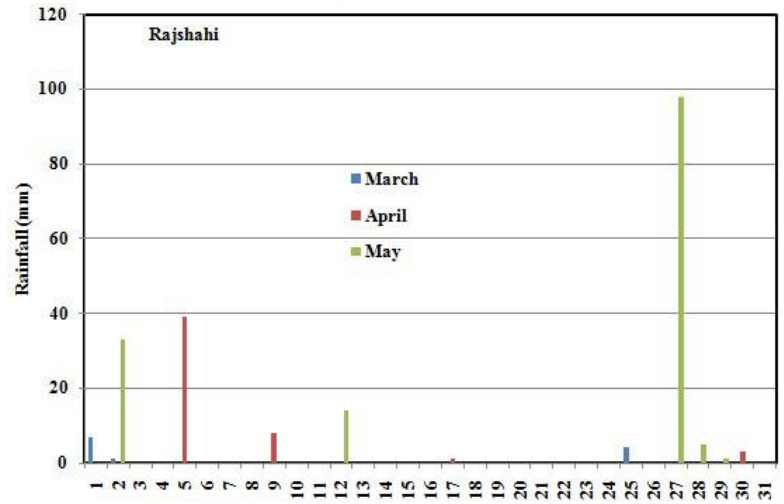

Days (March-May2014)

Figure 23: (a) Temporal variation of rainfall at Rajshahi during March-May 2014

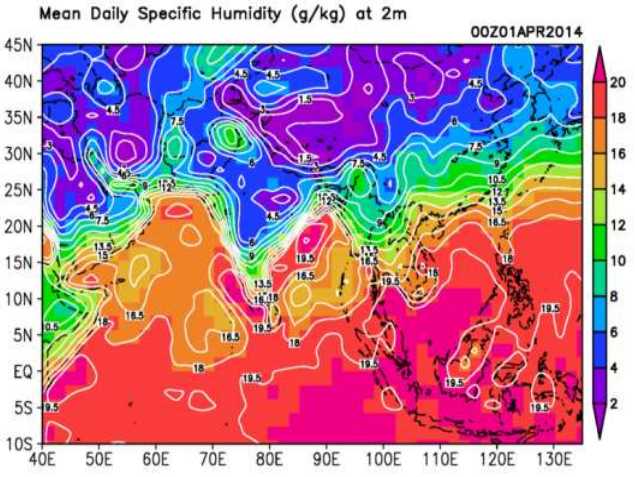

Figure 23: (b) Large-scale distribution of moisture in terms of specific humidity at $2 \mathrm{~m}$ on 1 April 2014 
The synoptic situation on 21 April 2014 also indicates the influence of STHP over India and adjoining Bangladesh pushing the low-pressure Myanmar and this situation is associated with no rainfall condition over Bangladesh and adjoining area (not shown for brevity). The sub-tropical high pressure is found to be very prominent of the areas north of Bangladesh and the whole Myanmar and China. The influence of the STHP over Bangladesh and adjoining area is associated with divergence in the eastern part of Bangladesh, thereby hindering the incursion of moisture over the country and seems to create the secondary heat wave over Chittagong Hill Tracts. As a result, less rainfall has occurred at Rajshahi for example in 2014 (Figure 23a). It is

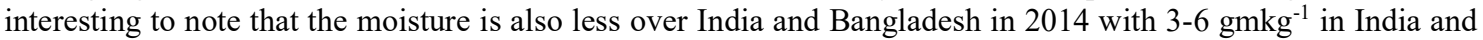
4-10 gmkg $^{-1}$ in Bangladesh (Figure 23b).

\subsection{Large-scale distribution of geopotential height at $850 \mathrm{hPa}$ level in 2014}

Large-scale distributions of geopotential height at $850 \mathrm{hPa}$ level have been investigated for the months of March through May 2014 to find out the causes of heat waves. In 2014, it has been found that there has been a narrow belt of low geopotential height over Uttar Pradesh, Bihar, West Bengal and adjoining area with a prominent high geopotential height $(1530 \mathrm{~m})$ extending from Gujrat through Madhya Pradesh, Chhattisgarh, Odissa Jharkhand and West Bengal to North Bay of Bengal and adjoining Bangladesh. Very high geopotential height is found to exist over Tibetan Plateau and adjoining areas. This high geopotential height indicates the presence of STHP over the area and it has pushed the low geopotential height area to the east from the Bay of Bengal towards northeast over Myanmar or more northeastward Figures 24(a-b). The STHP blocks the advection of moisture from the Bay of Bengal over Bangladesh, West Bengal and surroundings and hinders rain over the areas. The main reason of heat waves over the country has been due to the presence of this STH most of the times in 2014 . So, it is apparent that influence of STH has caused heat waves over Bangladesh in 2014.
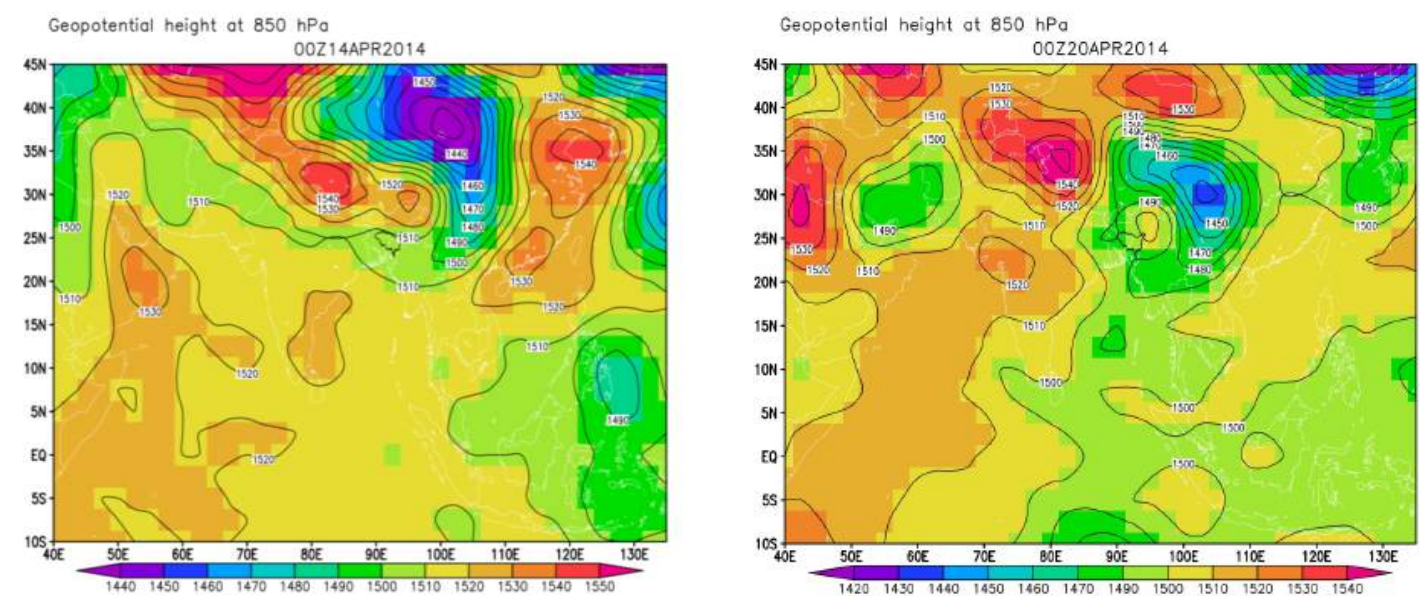

Figures 24: Large-scale distribution of geopotential height at $850 \mathrm{hPa}$ level on (a) 14 April 2014 and (b) 20 April 2014

\subsection{Large-Scale circulations at different levels associated with heat waves}

The large-scale circulation patterns associated with heat waves and non-heat waves in 2014 have been investigated for the pre-monsoon season to find the circulations responsible for heat waves. In 2014, there has been west-northwesterly wind over India extended to Bangladesh with no low-pressure area over Bihar/SubHimalayan West Bengal/West Bengal and adjoining Bangladesh at the surface and no circulation at $850 \mathrm{hPa}$ level over Bihar, West Bengal, Bangladesh (Figure 25a) during the pre-monsoon season. There has been no convergence of winds at $850 \mathrm{hPa}$ on most of the days in April 2014 over West Bengal and Bangladesh; rather there has been a strong anticyclonic flow over the northeast China near lat $37.5^{\circ} \mathrm{N}$ and long $130^{\circ} \mathrm{E}$, which has distant effect not to develop any convergence of wind over Bihar, West Bengal and Bangladesh. These situations indicate no rainfall conditions, and the westerly/northwesterly winds over India is responsible for the advection of higher temperature from northwest India and adjoining areas into Bangladesh to induce heat waves in the country.

There have been northwesterly winds at 500 over Uttar Pradesh, Madhya Pradesh, Bihar, West Bengal and Bangladesh on most of the days and an east-west oriented anticyclonic flow over the Arabian Sea and the Bay of Bengal. Strong cyclonic flow is found to exist over northeastern China (Figure 25b). The northwesterly winds Uttar Pradesh, Madhya Pradesh, Bihar, West Bengal and Bangladesh are responsible for the dry conditions, reducing rainfall and enhancing heat waves over the region. 
At $300 \mathrm{hPa}$ level, a ridge of anticyclonic flow is found over Pakistan and adjoining India with westerly to northwesterly winds of about $30 \mathrm{~ms}^{-1}$ wind, which become northwesterly to westerly with speed of 20-25 ms over north India, Madhya Pradesh, Bihar, West Bengal and Bangladesh on most of the days in April 2014 (Figure 25c). The positions of the anticyclones over the southern Bangladesh and adjoining Bay of Bengal are found to exist at $300 \mathrm{hPa}$ on some days too when southwesterly to westerly winds of about 30-40 ms ${ }^{-1}$ are found over India and Bangladesh (Figure 25d). This type of circulations, showing no convergence of winds over the area in April 2014 has been associated with heat waves over Bangladesh and India.
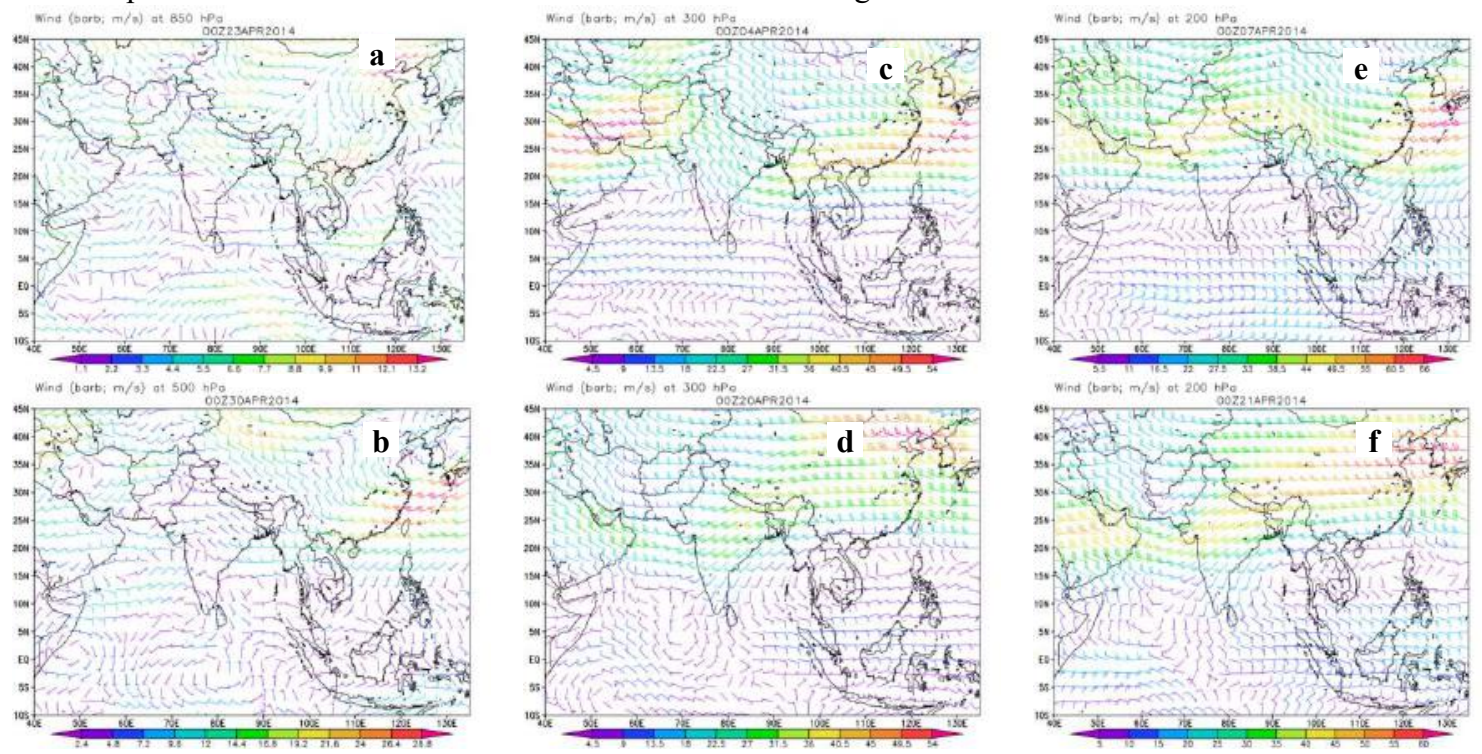

Figures 25: Large-scale circulation patterns at (a) $850 \mathrm{hPa}$ on 23 April 2014 and (b) $500 \mathrm{hPa}$ on 30 April 2014; at $300 \mathrm{hPa}$ (c) on 4 April 2014 and (d) on 20 April 2014 and patterns at $200 \mathrm{hPa}$ (e) on 7 April 2014 and (f) on 21 April 2014 over South Asia

The $200 \mathrm{hPa}$ level daily circulation patterns in month of April 2014 have been critically analyzed and interpreted. Some of the diagrams are given in Figures 25(e \& f) for April 2014. There have been strong westerly trough over Pakistan and adjoining areas extended southward over the Arabian Sea, a strong anticyclonic flow over the central/east central Bay of Bengal and adjoining Thailand and a strong ridge at 200 $\mathrm{hPa}$ over Bangladesh and adjoining India on most of the days with wind speed of $25-30 \mathrm{~ms}^{-1}$ over India and Bangladesh, and 45-50 $\mathrm{ms}^{-1}$ near the Himalayas and adjoining area. This ridge of the anticyclonic flow at 200 $\mathrm{hPa}$ over Bangladesh and India has enhanced the activity/influence of the anticyclone at the surface and 850 $\mathrm{hPa}$. As a result, there has been almost no rain in April 2014 and surrounding India thereby creating the situation of rising temperature in excess of $36^{\circ} \mathrm{C}$. This has resulted persistent heat waves of the country in April 2014.

\section{CONCLUSIONS}

On the basis of the present study, following conclusions can be drawn:

i. In 2014, $T_{\max } \geq 36^{\circ} \mathrm{C}$ is found to exist annually for many days in western part of Bangladesh in comparison to the eastern and coastal region of the country. $T_{\max } \geq 36^{\circ} \mathrm{C}$ is found to prevail annually for 79 days at Rajshahi, 51 days at Mongla, 50 days at Khulna in 2014 whereas $T_{\max } \geq 36^{0} \mathrm{C}$ is found to prevail annually for 85 days at Chuadanga in 1992, 78 days at Jessore in 2010, 72 days at Satkhira in 1986 and 68 days at Ishurdi in 1995.

ii. Seasonal and annual frequency of $T_{\max } \geq 36^{\circ} \mathrm{C}$ have increasing trends during 1981-2016 in Bangladesh except a very few places, having the highest increasing trends over southwestern part of the country with increasing rates of 0.816 and 1.02 day/year, respectively at Mongla. The higher increasing trend of annual frequency of $T_{\max } \geq 36^{\circ} \mathrm{C}$ is due to the fact that maximum temperature also attains $\geq 36^{\circ} \mathrm{C}$ during the southwest monsoon season. The increasing rates of seasonal as well as annual frequency of $T_{\text {max }} \geq 36^{\circ} \mathrm{C}$ are statistically significant at about $50 \%$ stations up to $95-99 \%$ level of significance.

iii. The seasonal frequency of days with $T_{\text {max }} \geq 38^{\circ} \mathrm{C}$ has decreasing trends at $51.61 \%$ stations with the highest decreasing rate of -0.067 day/year at Satkhira and Ishurdi; whereas the seasonal frequency of days with $T_{\max } \geq 38^{\circ} \mathrm{C}$ has increasing trends at $48.39 \%$ stations. While the annual frequency of days with $T_{\max } \geq 38^{\circ} \mathrm{C}$ has increasing trends at $45.16 \%$ stations with the highest increasing rate of +0.261 day/year at Chandpur and the second highest increasing rate of +0.242 days/year at Mongla. 
iv. Heat waves extend from west to east up to about central Bangladesh and a separate area of heat waves develop over the Chittagong Hill Tracts, the reason of which may be due to the diverging pattern of wind flows near the Chittagong Hill Tracts in the year of heat waves. Heat waves are absent along the region Sandwip-M.Court-Feni-Comilla region.

v. The maximum temperature during March through May 2014 have been above $4^{\circ} \mathrm{C}$ to about $12-14^{\circ} \mathrm{C}$ above normal dry-bulb temperature for several days, indicating mild to severe heat waves in the country.

vi. In 2014, there have been 54-55 days with $T_{\max } \geq 36^{\circ} \mathrm{C}$ and $31-35$ days with $T_{\max } \geq 38^{0} \mathrm{C}$ in the premonsoon season in Jessore-Chuadanga region, indicating heat waves of mild-severe and moderatesevere intensity. Annually, there have been about 69-79 days with $T_{\max } \geq 36^{\circ} \mathrm{C}$ and 35-36 days with $T_{\max } \geq 38^{\circ} \mathrm{C}$ in the western part of the country in 2014 . Heat waves are absent along the region Sandwip-M.Court-Feni-Comilla region.

vii. The $T_{\max }$ in 2014 is found to exceed $36^{\circ} \mathrm{C}$ and persist for many days continuously especially in the months of April and May whereas maximum temperature in 2018 has exceeded $36^{\circ} \mathrm{C}$ occasionally except in April where there are some days with mild heat waves. Heat waves enter Bangladesh from the west/ northwest due to the advection of higher maximum temperature from the west.

viii. Heat waves are generated mainly due to the presence of less moisture, prominent influence of subtropical high over India and its extension over Bangladesh at the surface extended vertically to $850 \mathrm{hPa}$ level or more upwards, the influence of anticyclonic circulation/ridge of anticyclonic circulation in the upper troposphere up to $200 \mathrm{hPa}$ with strong westerly/northwesterly jet streams over Bangladesh and adjoining area and less rainfall.

\section{ACKNOWLEDGEMENTS}

The authors are grateful to the Ministry of Science and Technology, Government of the People's Republic of Bangladesh for approving and supporting the present research project "Study on Heat Waves and Associated Large-scale Circulations in Bangladesh" with financial support. The authors would like to thank the Chairman of National Oceanographic and Maritime Institute (NOAMI) for providing necessary facilities to carry out the project work at NOAMI. The authors would like to thank Mr. Shamsuddin Ahmed, Director of Bangladesh Meteorological Department (BMD) for providing relevant meteorological data for the project. Appreciable thanks are due to NCEP/NCAR, USA, for making the Reanalysis 1 Project Data freely available to the research community.

\section{REFERENCES}

De, U. S., and Mukhopadhyay R. K., 1998. Severe heat wave over Indian subcontinent in 1998 in a perspective of global climate, Current Science, 75, 1308-1311.

De, U. S., Khole M., and Dandekar M., 2004. Natural hazards associated with meteorological extreme events, Nat. Hazards, 31, 487-497.

Ghatak, D., Zaitchik B., Hain C., and Anderson M., 2017. The role of local heating in the 2015 Indian Heat Wave, Sci Rep 7, 7707. https://doi.org/10.1038/s41598-017-07956-5

Hashizume, M., Armstrong B., Hajat S., Wagatsuma Y., Faruque A. S., Hayashi T., and Sack D.A., 2008. The effect of rainfall on the incidence of cholera in Bangladesh, Epidemiology, 19(1), 103-10.

Joost R. van Ginkel, 2019. Significance Tests and Estimates for $R^{2}$ for Multiple Regression in Multiply Imputed Datasets: A Cautionary Note on Earlier Findings, and Alternative Solutions, Multivariate Behavioral Research, 54:4, 514-529, DOI: 10.1080/00273171.2018.1540967

Karmakar, S., 2019. Patterns of climate change and its impacts in northwestern Bangladesh. Journal of Engineering science, 10(20), 33-48.

Mishra, V., Ganguly A. R., Nijssen B., and Lettenmaier D. P., 2015. Changes in observed climate extremes in global urban areas, Environ. Res. Lett. 10, 2, 024005 10.1088/1748-9326/10/2/024005.

Mitra, V., Mukherjee S., Kumar R., and Stone D. A., 2017. Heat wave exposure in India in current, $1.5^{\circ} \mathrm{C}$, and 2.0॰ C worlds, Environ. Res. Lett., 12, 124012, 1-9, https://doi.org/10.1088/1748-9326/aa9388.

Murari, K., Ghosh S., Patwardhan A., Daly E., and Salvi K., 2015. Intensification of future severe heat waves in India and their effect on heat stress and mortality. Regional Environmental Change, 15, pp.569-57.

Nissan, H., Burkat K., de Prez E. C., Aalst M.V., and Mason S., 2017. Defining and Predicting Heat Waves in Bangladesh, Journal of Applied Meteorology, 56, 2653-2670.

Pai, D.S., Nair S.A., and Ramanathan A.N., 2013. Long term climatology and trends of heat waves over India during the recent 50 years (1961-2010), Mausam, 64(4), 585-604.

Panda, D. K., Agha Kouchak A., and Ambast S. K., 2017. Increasing heat waves and warm spells in India, observed from a multiaspect framework, Journal Geographical Research: Atmosphere, 122(7), 1-22. 
Ratnam, J.V., Behera1 S.K., Ratna S. B., Rajeevan M., and Yamagata T., 2016. Anatomy of Indian heat waves, Scientific Reports | 6:24395 | DOI: 10.1038/srep24395 1 www.nature.com/scientificreports, pp. 1-11. (file:///C:/Users/User\%20Old/Documents/Anatomy_of_Indian_heatwaves.pdf) 